\title{
A dissolved cobalt plume in the oxygen minimum zone of the eastern tropical South Pacific
}

\author{
Nicholas J. Hawco ${ }^{1,2}$, Daniel C. Ohnemus ${ }^{3}$, Joseph A. Resing ${ }^{4}$, Benjamin S. Twining ${ }^{3}$, and Mak A. Saito ${ }^{2}$ \\ ${ }^{1}$ MIT/WHOI Joint Program in Oceanography/Applied Ocean Science and Engineering, Woods Hole, MA, USA \\ ${ }^{2}$ Department of Marine Chemistry and Geochemistry, Woods Hole Oceanographic Institution, Woods Hole, MA, USA \\ ${ }^{3}$ Bigelow Laboratory for Ocean Sciences, East Boothbay, ME, USA \\ ${ }^{4}$ Joint Institute for the Study of the Atmosphere and the Ocean, University of Washington and \\ NOAA-PMEL, Seattle, WA, USA
}

Correspondence to: Mak A. Saito (msaito@whoi.edu)

Received: 29 April 2016 - Published in Biogeosciences Discuss.: 18 May 2016

Revised: 13 September 2016 - Accepted: 21 September 2016 - Published: 17 October 2016

\begin{abstract}
Cobalt is a nutrient to phytoplankton, but knowledge about its biogeochemical cycling is limited, especially in the Pacific Ocean. Here, we report sections of dissolved cobalt and labile dissolved cobalt from the US GEOTRACES GP16 transect in the South Pacific. The cobalt distribution is closely tied to the extent and intensity of the oxygen minimum zone in the eastern South Pacific with highest concentrations measured at the oxycline near the Peru margin. Below $200 \mathrm{~m}$, remineralization and circulation produce an inverse relationship between cobalt and dissolved oxygen that extends throughout the basin. Within the oxygen minimum zone, elevated concentrations of labile cobalt are generated by input from coastal sources and reduced scavenging at low $\mathrm{O}_{2}$. As these high cobalt waters are upwelled and advected offshore, phytoplankton export returns cobalt to low-oxygen water masses underneath. West of the Peru upwelling region, dissolved cobalt is less than $10 \mathrm{pM}$ in the euphotic zone and strongly bound by organic ligands. Because the cobalt nutricline within the South Pacific gyre is deeper than in oligotrophic regions in the North and South Atlantic, cobalt involved in sustaining phytoplankton productivity in the gyre is heavily recycled and ultimately arrives from lateral transport of upwelled waters from the eastern margin. In contrast to large coastal inputs, atmospheric deposition and hydrothermal vents along the East Pacific Rise appear to be minor sources of cobalt. Overall, these results demonstrate that oxygen biogeochemistry exerts a strong influence on cobalt cycling.
\end{abstract}

\section{Introduction}

Cobalt is the least abundant inorganic nutrient in seawater, and its scarcity may affect phytoplankton growth in certain regions (Moore et al., 2013). In the high macronutrient waters of the Costa Rica upwelling dome, for instance, Co and iron $(\mathrm{Fe})$ amendments to surface seawater increased phytoplankton production more than $\mathrm{Fe}$ alone, promoting growth of the cyanobacterium Synechococcus (Ahlgren et al., 2014; Saito et al., 2005). While eukaryotic phytoplankton mainly use cobalt to compensate for insufficient zinc (Sunda and Huntsman, 1995), populating the same enzymes with either metal (Yee and Morel, 1996), marine cyanobacteria have an absolute growth requirement for Co that cannot be substituted, which suggests they may be more prone to limitation (Saito et al., 2002). Yet the extent to which their growth in situ is affected by cobalt scarcity ultimately depends on the processes that add Co to, or remove it from, the surface ocean relative to other limiting nutrients.

Biological cycling of dissolved cobalt $(\mathrm{dCo})$ is apparent in vertical profiles, showing uptake and export in the surface and regeneration in the thermocline (Bown et al., 2011; Dulaquais et al., 2014a; Noble et al., 2012). While dCo in the euphotic zone can be entirely bound by strong organic ligands, a substantial portion of subsurface dCo is unbound and labile (10-50\%; Bown et al., 2012; Ellwood and van den Berg, 2001; Saito and Moffett, 2001; Saito et al., 2005) and therefore vulnerable to scavenging (Moffett and Ho, 1996). The similar ionic radii and redox potentials of 


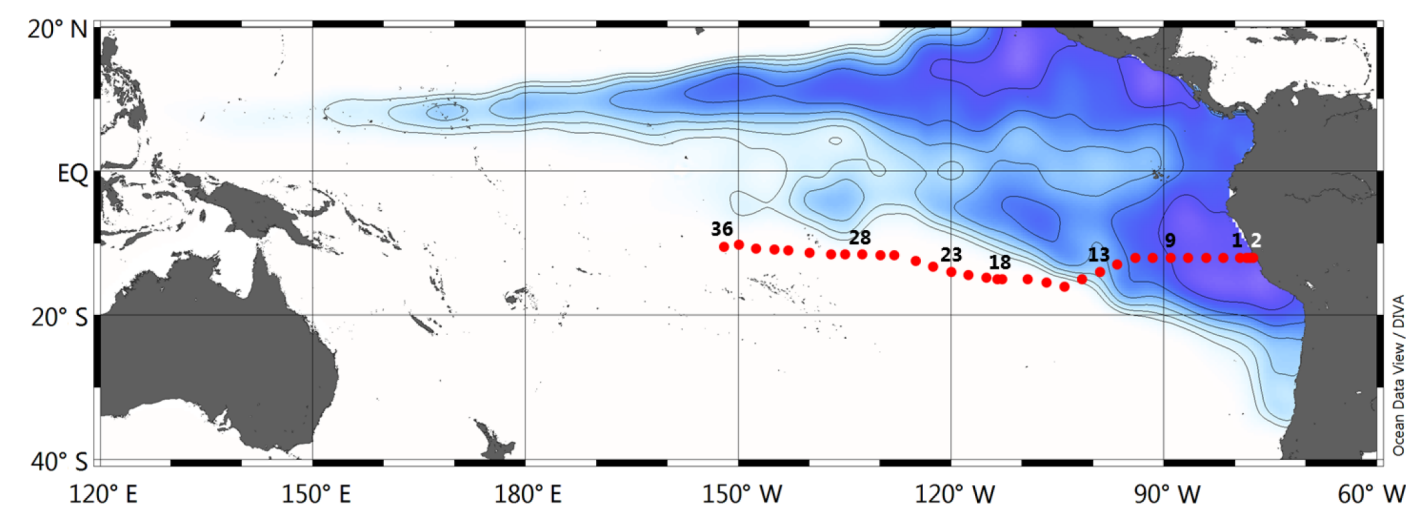

Figure 1. The GP16 transect in the tropical South Pacific. Red circles indicate sampling stations. Dissolved oxygen at a depth of $300 \mathrm{~m}$ from the World Ocean Circulation Experiment dataset is plotted in blue and $10 \mu \mathrm{M}$ contours are shown between $0-60 \mu \mathrm{MO} \mathrm{O}_{2}$. Station number increases sequentially westward, with the exception of Station 1.

cobalt and manganese (Mn) cause dCo to be actively incorporated into bacterially produced Mn oxides, which sink from the water column and accumulate in marine sediments (Cowen and Bruland, 1985; Moffett and Ho, 1996; Swanner et al., 2014). Below the euphotic zone, the persistence of labile dissolved cobalt (LCo) throughout the Atlantic indicates that scavenging of $\mathrm{dCo}$, unlike $\mathrm{Fe}$, is slow (Noble et al., 2012). On timescales of ocean circulation, however, scavenging is responsible for decreasing dCo concentrations with depth and for the low ratio between $\mathrm{dCo}$ and macronutrients in deep waters relative to phytoplankton biomass (Moore et al., 2013). As these deep waters are repackaged into thermocline water masses and eventually brought to the surface (Sarmiento et al., 2011), the upper ocean would become depleted in cobalt - as well as other hybrid metals like Fe and $\mathrm{Mn}$ - without external sources that keep pace with scavenging (Bruland and Lohan, 2003; Noble et al., 2008).

Yet the nature of marine cobalt sources is uncertain. In zonal sections of the North and South Atlantic, sources appear to be concentrated along continental margins (Noble and Saito, 2016; Noble et al., 2012). In the western Atlantic, dCo concentrations exceeding $100 \mathrm{pM}$ were associated with the flow of Upper Labrador Seawater, likely gained through intense sediment resuspension along the shelf or input prior to subduction (Noble and Saito, 2016). dCo in fresh and estuarine waters can be 100-1000 times greater than seawater (Gaillardet et al., 2003; Knauer et al., 1982; Tovar-Sánchez et al., 2004), and Co is less prone to flocculation in estuaries than other metals (Sholkovitz and Copland, 1982). Terrigenous inputs from the American continent can be clearly seen in lower-salinity surface waters influenced by the Gulf Stream (Noble and Saito, 2016; Saito and Moffett, 2002) and Amazon discharge (Dulaquais et al., 2014b). Yet in both the North and South Atlantic, a much larger dCo plume was associated with the oxygen minimum zones (OMZs) along the Mauritanian and Namibian coasts (Noble and Saito, 2016, Noble et al., 2012). Although these waters are not anoxic, the
dCo plumes imply that $\mathrm{O}_{2}$ over the continental shelf is sufficiently low that reductive dissolution of $\mathrm{Mn}$ and $\mathrm{Fe}$ oxides in sediments releases a large flux of dCo to the water column (Heggie and Lewis, 1984; Sundby et al., 1986). Drawing on large inventories in the Atlantic OMZs, upwelling along eastern margins provides a large dCo flux to the surface ocean. While surface dCo maxima from atmospheric deposition generally do not appear in vertical profiles, this process may be important for regions that are isolated from continental input or receive very high levels of dust (e.g., the Sargasso Sea, Dulaquais et al., 2014a; Shelley et al., 2012).

To date, sectional datasets for dCo have been confined to the Atlantic, and, as such, our understanding of cobalt cycling may be biased by the dominant processes occurring there. In comparison, the South Pacific receives considerably less dust deposition and river input (Mahowald et al., 2005; Milliman and Farnsworth, 2011) but hosts a much larger and more reducing oxygen minimum zone. Surface transects off Peru and the Costa Rica Dome suggest a large source from upwelling (Ahlgren et al., 2014; Saito et al., 2004, 2005); however, profiles in the tropical Pacific are sparse (Noble et al., 2008; Saito et al., 2014). We measured the concentration of dissolved cobalt and labile dissolved cobalt in over 750 samples collected onboard the 2013 US GEOTRACES GP16 expedition across the South Pacific along $12^{\circ} \mathrm{S}$, intersecting coastal upwelling along the Peru margin, hydrothermal venting over the East Pacific Rise, and oligotrophic conditions near Polynesia (Fig. 1). Across this section, the distribution of dCo and LCo follows the intensity of the oxygen minimum zone, with highest concentrations near the South American shelf and low concentrations in both deep waters and oligotrophic surface waters, matching OMZ-associated plumes observed in the Atlantic. 


\section{Methods}

\subsection{Sample collection and handling}

Sampling for GP16 was conducted with a 24-position trace metal clean titanium rosette attached to a nonmetallic Kevlar cable designed for the US GEOTRACES program (Cutter and Bruland, 2012). An additional sample was collected from a surface towfish at each station. Subsamples were collected in a Class-100 sampling van from $12 \mathrm{~L}$ Go-Flo bottles (General Oceanics) and passed through $0.2 \mu \mathrm{m}$ Acropack filters (Pall). All bottles were rinsed three times with sample seawater before being filled entirely, leaving no headspace. For samples analyzed at sea, both dissolved and labile cobalt were measured from the same bottle. All samples were kept refrigerated at $4{ }^{\circ} \mathrm{C}$ until analysis in a HEPA-filtered clean van. All of the LCo samples and more than $90 \%$ of dCo samples were analyzed at sea. Samples not analyzed at sea were preserved for $\mathrm{dCo}$ immediately after sampling using metal-free gas-adsorbing satchels (Mitsubishi Gas Chemical, model RP-3K), using three to four satchels per six seawater samples. Gas-impermeable plastic bags (Ampac) were heat sealed and were hand carried directly to Woods Hole Oceanographic Institution (WHOI) at $4{ }^{\circ} \mathrm{C}$ following disembarkation.

\subsection{Cobalt determination by cathodic stripping voltammetry}

dCo and LCo were measured using a cathodic stripping voltammetry (CSV) method optimized for organic speciation by Saito and Moffett (2001). This method relies on the complexation of inorganic Co species by a strong synthetic ligand, dimethylglyoxime (DMG, $\mathrm{K}^{\text {cond }}=10^{11.5 \pm 0.3}$ ), which forms a bis-complex, $\mathrm{Co}(\mathrm{DMG})_{2}$, with $\mathrm{Co}^{2+}$ that readily adsorbs to a hanging mercury drop (Saito and Moffett, 2001). The $\mathrm{Co}(\mathrm{DMG})_{2}$ complex is measured following a fast, $10 \mathrm{~V} \mathrm{~s}^{-1}$ sweep that reduces both the $\operatorname{Co}(\mathrm{II})$ to $\operatorname{Co}(0)$ and the DMG to 2,3-bis(hydroxylamino)butane, producing an 810 electron decrease in current for each $\mathrm{Co}(\mathrm{DMG})_{2}$ complex (Baxter et al., 1998). The height of the $\mathrm{Co}(\mathrm{DMG})_{2}$ reduction peak at $-1.15 \mathrm{~V}$ is directly proportional to the Co concentration.

Triplicate scans of the seawater sample were followed by four standard cobalt additions ( $25 \mathrm{pM}$ per addition), and the slope of their linear regression (mean $R^{2}=0.998$ ) was used to calculate the sample-specific sensitivity (in $\mathrm{nA} \mathrm{pM}^{-1}$ ). The cobalt concentration was determined by dividing the mean of the three baseline peaks by the sensitivity and correcting for reagent volume. The average deviation for these triplicate scans was $1.5 \mathrm{pM}$.

dCo analyses were conducted after a $1 \mathrm{~h} \mathrm{UV}$ oxidation procedure to remove strong organic ligands that prevent DMG from binding Co. UV digestion was performed in $15 \mathrm{~mL}$ quartz glass tubes using a Metrohm 705 UV digester
(Metrohm USA). Temperature was maintained below $20^{\circ} \mathrm{C}$ to minimize evaporation losses. After UV digestion, $11 \mathrm{~mL}$ of sample was pipetted into a $15 \mathrm{~mL}$ polypropylene tube and DMG and a buffering agent, EPPS, were added to final concentrations of $400 \mu \mathrm{M}$ and $3.8 \mathrm{mM}$, respectively. Overall, $8.5 \mathrm{~mL}$ of sample solution was added to a Teflon analysis cup and mixed with $1.5 \mathrm{~mL}$ of $1.5 \mathrm{M} \mathrm{NaNO}_{2}$, making a final analysis volume of $10 \mathrm{~mL}$.

LCo was measured after more than $8 \mathrm{~h}$ incubation of $11 \mathrm{~mL}$ of seawater with $400 \mu \mathrm{M}$ DMG in a Teflon vial. LCo is therefore the concentration that will readily exchange with DMG. After this time, the sample was poured into an autosampler-compatible $15 \mathrm{~mL}$ polypropylene tube (separate from those used for dCo analyses) and EPPS was added to $3.8 \mathrm{mM}$.

\subsubsection{Preparing reagent and blanks}

All bottles and sample tubes were soaked for more than 1 week in the acidic detergent Citranox, rinsed thoroughly with 18.2 $\mathrm{M} \Omega$ water (Millipore), filled with $10 \%$ trace-metalgrade $\mathrm{HCl}$ (J. T. Baker, Center Valley, PA, USA) to soak for 10 days, and rinsed thoroughly with $\sim 10 \mathrm{mM}$ TM-grade $\mathrm{HCl}$. DMG (Sigma-Aldrich) was purified by recrystallization in a $1 \mathrm{mM}$ EDTA solution (Sigma-Aldrich). Crystals were filtered, dried, and dissolved in HPLC-grade methanol to a concentration of $0.1 \mathrm{M}$ (Saito and Moffett, 2001). EPPS (Fischer) and sodium nitrite (Millipore) were both dissolved in Milli-Q water to 0.5 and $1.5 \mathrm{M}$, respectively, and treated with separate batches of thoroughly cleaned Chelex-100 beads (Bio-Rad) to remove background $\mathrm{Co}$ and Ni (Price et al., 1989). Standard additions of cobalt were generated by diluting a $1 \mathrm{ppm}$ certified reference standard (SPEX Certiprep) with $10 \mathrm{mM} \mathrm{HCl}$ to a concentration of $5.00 \mathrm{nM}$. In total, $50 \mu \mathrm{L}$ of this solution was added to the $10 \mathrm{~mL}$ sample volume for each standard addition ( $25 \mathrm{pM}$ addition).

To determine reagent blanks, Co-free seawater was generated by treating UV seawater with cleaned Chelex-100 beads. The seawater was then UV digested a second time to remove any ligands leached during Chelex treatment. Any dCo measured in the Chelexed seawater derives from addition of Co from analytical reagents. The mean blank for at-sea analysis was consistently low: $3.7 \pm 1.2 \mathrm{pM}(n=28)$. For analyses at Woods Hole, the mean blank was $4.7 \pm 1.4 \mathrm{pM}(n=12)$. Blanks were subtracted from all measured values. Detection limits were calculated as triple the standard deviation of the blank: $3.6 \mathrm{pM}$ for at-sea analyses and $4.2 \mathrm{pM}$ for samples measured in Woods Hole.

\subsubsection{Automated cobalt analyses}

To accommodate a greater number of samples, our previous workflow (Noble et al., 2008) was modified to incorporate fully automated sample analyses using the Metrohm 858 Sample Processor autosampler. All measurements were per- 


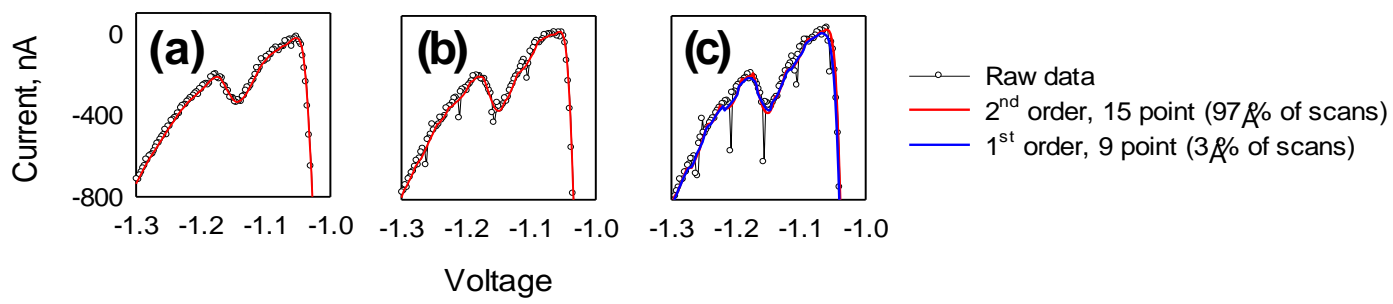

Figure 2. Signal processing of voltammetry scans. Varying instrumental noise imprinted negative current excursions during measurement and necessitated data smoothing to correctly measure the $\operatorname{Co}(\mathrm{DMG})_{2}$ reduction peak at $-1.15 \mathrm{~V}$. For mild (a) and moderate (b) noise levels, a second-order, 17-point smoothing was applied (red line, $97 \%$ of scans). Increases in noise caused this routine to overestimate peak height (c, red line), and a first-order, 13-point smoothing was applied instead ( $\sim 3 \%$ of scans, blue line).

formed using an Eco-Chemie $\mu$ AutolabIII system connected to a Metrohm 663 VA stand. A hanging-drop mercury electrode (Metrohm) was set to semi-hanging-drop mode and accompanied by a $3 \mathrm{M} \mathrm{KCl} / \mathrm{AgCl}$ reference electrode and glassy carbon auxiliary electrode. Scheduling and data acquisition were controlled using NOVA 1.8 software (Metrohm Autolab B.V). Automated delivery of seawater, sodium nitrite, and Co standard to the analysis cup was accomplished by three dedicated Dosino 800 burettes (Metrohm). Sample volume was increased to allow $\sim 2 \mathrm{~mL}$ for conditioning tubing and analysis cup prior to sample delivery.

Tubes containing $11 \mathrm{~mL}$ seawater, DMG, and EPPS were inverted several times and placed onto a sampling rack where $8.5 \mathrm{~mL}$ of the mixture was dosed into the Teflon analysis cup. Then, $1.5 \mathrm{~mL}$ of $1.5 \mathrm{M}$ sodium nitrite was added directly to the sample cup. Samples were purged with highpurity $\mathrm{N}_{2}(>99.99 \%)$ for $180 \mathrm{~s}$ and then conditioned for $90 \mathrm{~s}$ at $-0.6 \mathrm{~V}$. Scan sweeps were run at $10 \mathrm{~V} \mathrm{~s}^{-1}$ from -0.6 to $-1.4 \mathrm{~V}$. Before each analysis, the sample cup was rinsed fully with Milli-Q water and $1 \mathrm{~mL}$ sample before measurement. Between uses, autosampler tubes, quartz vials, and Teflon cups were rinsed with $10 \mathrm{mM} \mathrm{HCl}, 18.2 \mathrm{M} \Omega$ water, and $1-2 \mathrm{~mL}$ of new sample. The autosampler uptake line was rinsed with $10 \mathrm{mM} \mathrm{HCl}$ and $18.2 \mathrm{M} \Omega$ water when transitioning from LCo analyses to dCo analyses.

We noticed a decrease in sensitivity of preserved samples relative to those analyzed at sea, possibly caused by an increase in the sample $\mathrm{pH}$ during storage. Sensitivity was restored by doubling the concentration of our buffering agent, EPPS, in the sample to a final concentration of $7.6 \mathrm{mM}$. We tested a broad range of EPPS additions in UV seawater and found the cobalt concentration unchanged, while the variance between triplicate scans was reduced markedly by the increase in sensitivity (data not shown). We tentatively attribute this decrease in sensitivity in preserved samples to $\mathrm{CO}_{2}$ adsorption by gas satchels, which would increase sample $\mathrm{pH}$.

\subsubsection{Signal processing}

Analyses conducted at sea were characterized with a mild to moderate electrical interference that mandated additional processing before peak height could be reliably measured (Fig. 2). We opted for a simplified least squared fitting routine included in the NOVA software package that conducts a 15 -point weighted moving average - equivalent to a $36.9 \mathrm{mV}$ window - according to a second-order polynomial. This method did not distort measured peak height when noise was low (Fig. 2a, b). A small fraction of scans $(\sim 3 \%)$ were not adequately fit using this routine and were instead smoothed using a nine-point linear moving average $(22.1 \mathrm{mV}$ window, Fig. 2c), also included in NOVA. For all samples, peak height was measured manually to minimize peak distortion due to added noise.

Subsequent analyses in the laboratory at Woods Hole were able to remove this signal by increasing the current sampling step from $2.46 \mathrm{mV}$ (341 points between -0.6 and $-1.4 \mathrm{~V}$ ) to $4.88 \mathrm{mV}$ (174 points), which eliminated the need for smoothing prior to sample analysis. We observed good agreement between samples analyzed at sea and in the lab, indicating that the smoothing procedures applied at sea did not bias the data and that gas-adsorbing satchels preserved original concentrations (Noble and Saito, 2016).

\subsubsection{Intercalibration and internal laboratory standard}

All data reported in this manuscript have been submitted to the Biological and Chemical Oceanography Data Management Center (BCO-DMO, http://www.bco-dmo.org/dataset/ 647250). Our laboratory continues to participate in international intercalibration efforts through the GEOTRACES program in anticipation of the release of the 2nd Intermediate Data Product, Summer 2017. The sampling scheme for GP16 included two overlapping samples per full depth profile where the shallowest sample of the deep cast was collected at the same depth as the deepest sample for the mid cast, and the shallowest sample from the mid cast was collected at the same depth as the deepest sample from the shallow cast (i.e., a 36-point profile is composed of 34 discreet depths and 2 overlapping depths). Comparing overlapping samples collected at the same depth and location on separate hydrocasts provides a measure of reproducibility. The average difference between dCo analyses across 40 overlap- 
Table 1. Blanks and standards used during analyses.

\begin{tabular}{llrrrc}
\hline & & $\mathrm{dCo}, \mathrm{pM}$ & \pm & $n$ & Consensus \\
\hline At sea & Blank & 3.7 & 1.2 & 28 & \\
Oct-Dec, & Lab SW $^{\mathrm{a}}$ & 4.5 & 2.1 & 28 & \\
2013 & D1 & 48.5 & 2.4 & 3 & $46.6 \pm 4.8$ \\
\hline At WHOI, & Blank & 4.7 & 1.4 & 12 & \\
Sep-Nov, & GSP & 2.5 & 2.0 & 10 & $4.9 \pm 1.2^{\mathrm{b}}$ \\
2014 & D2 & 45.0 & 2.7 & 7 & $46.9 \pm 3.0$ \\
& GSC & 77.7 & 2.4 & 4 & $\mathrm{c}$ \\
\hline
\end{tabular}

${ }^{a}$ South Pacific surface seawater, collected November 2011. ${ }^{b}$ Refers to SAFe standard S, collected at the same location as GSP. ${ }^{\mathrm{c}}$ No consensus.

ping depth samples was $5.7 \mathrm{pM}$, with a median difference of $3.5 \mathrm{pM}$. For labile cobalt, average deviation was $2.1 \mathrm{pM}$ (median of $2.0 \mathrm{pM}, n=41$ ). Least-squares regression of these samples yielded slopes close to 1 ( 0.98 for $\mathrm{dCo}$ and 0.96 for LCo; $y$ intercept forced to 0 ), indicating good reproducibility. Furthermore, comparisons with other groups measuring $\mathrm{dCo}$ in the same samples reported here suggest strong agreement between groups despite major methodological differences (C. Parker and K. Bruland, personal communication, 2016).

Because acidified community reference materials such as the SAFe standards require a delicate neutralization to $\mathrm{pH} 7.5-8$ prior to analysis, a large batch of UV oligotrophic seawater was generated prior to the cruise and used to assess instrument performance during at-sea analysis. This consistency seawater standard was run roughly three times per week, as were blanks, and values were stable over several reagent batches for the duration of the cruise $(4.5 \pm 2.1 \mathrm{pM}$, $n=28$ ) (Table 1). SAFe standard D1 was measured at sea $(48.5 \pm 2.4 \mathrm{pM}, n=3)$ and fell within $1 \mathrm{SD}$ of the consensus value $(46.6 \pm 4.8 \mathrm{pM})$. SAFe standard D2 and GEOTRACES standard GSP were run at higher frequency for analyses at Woods Hole. Our measurements of D2 $(46.9 \pm 3.0 \mathrm{pM}$, $n=7)$ agreed with consensus values $(45.7 \pm 2.9 \mathrm{pM})$ and concentrations from our lab published previously (Noble et al., 2012). While the GSP standard does not have a consensus value, our determinations $(2.5 \pm 2.0 \mathrm{pM}, n=10)$ are within the range for SAFe $\mathrm{S}(4.9 \pm 1.2 \mathrm{pM})$, which was collected at the same offshore location as GSP. Acidified SAFe and GEOTRACES standards were neutralized with concentrated ammonium hydroxide (Seastar), mixing the entire sample between drops, prior to UV digestion. When base was added more quickly, measured dCo was halved, presumably due to adsorption or coprecipitation onto magnesium hydroxides formed during base addition. For analysis of neutralized standards, we found that a $\sim 6: 1 \mathrm{EPPS}: \mathrm{NH}_{4} \mathrm{OH}(\mathrm{M}: \mathrm{M})$ buffer improved $\mathrm{pH}$ stability during analysis and removed significant baseline drift observed with samples solely buffered with EPPS.

\subsection{Particulate-metal analyses}

Particulate material collected from Go-Flo bottles was filtered onto acid-cleaned $0.45 \mu \mathrm{m}$ polyethersulfone filters $(25 \mathrm{~mm})$. Digestion protocol and analyses are identical to those used to measure particulate metal concentrations during the North Atlantic GA03 cruise, described in Twining et al. (2015). After filtration, filters were halved and digested at $135^{\circ} \mathrm{C}$ in sealed Teflon vials containing $4 \mathrm{M} \mathrm{HCL}$, $4 \mathrm{MHNO}_{3}$, and $4 \mathrm{MHF}$; digests were then dried and redissolved in $0.32 \mathrm{MHNO}_{3}$ before analysis. pCo, pMn and $\mathrm{pP}$ concentrations were measured by inductively coupled plasma mass spectrometry (ICP-MS) (Element 2, Thermo Scientific), calibrated using external multi-element standard curves, and corrected for instrument drift and sample recovery by In and Cs internal standards. More detailed methods for this dataset can be found elsewhere (Ohnemus et al., 2016).

\section{Results}

We report 680 determinations of dissolved cobalt (dCo) and 783 determinations of labile dissolved cobalt (LCo) measured at sea, onboard the GP16 expedition in OctoberDecember 2013, as well as an additional 140 measurements of dCo measured from preserved samples on land. In this section, we describe the distributions of dCo, particulate cobalt (pCo), and LCo in the South Pacific Ocean.

\subsection{Dissolved cobalt $(\mathrm{dCo})$}

Throughout the GP16 transect, nutrient uptake and scavenging result in a hybrid-type profile for dCo (Fig. 3), similar to dCo profiles from the Atlantic (Bown et al., 2011; Dulaquais et al., 2014b; Noble et al., 2012; Noble and Saito, 2016) and North Pacific (Ahlgren et al., 2014; Knauer et al., 1982; Saito et al., 2014). dCo ranged from $<3 \mathrm{pM}$ (below detection) in the South Pacific gyre (e.g., stations 23, 36) to $210 \mathrm{pM}$ beneath the oxycline near the Peru margin (Station 1). In the deep Pacific, concentrations fell between 20 and $40 \mathrm{pM}$ but increased slightly at deepest stations below $4500 \mathrm{~m}$. These values are much less than those observed in zonal transects surveying the North and South Atlantic (Noble et al., 2012; Noble and Saito, 2016) but are similar to measurements in the Southern Ocean (Bown et al., 2011), indicating that $\mathrm{dCo}$ is scavenged in the deep ocean along meridional overturning circulation. Below $3000 \mathrm{~m}$, dCo is somewhat lower east of the East Pacific Rise (EPR) and matches less oxygenated, older waters than in the western portion of the transect (Fig. 4). While many profiles west of the EPR show considerable variation between 2000 and $3000 \mathrm{~m}$, suggestive of hydrothermal influence, the range is small $(<10 \mathrm{pM})$ relative to background concentrations (30$40 \mathrm{pM}$ ) and unlike the 50-fold excess of hydrothermal $\mathrm{dFe}$ 

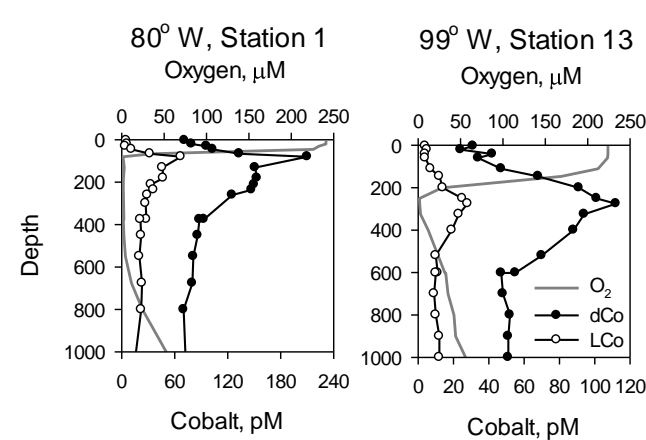

Oxygen, $\mu \mathrm{M}$
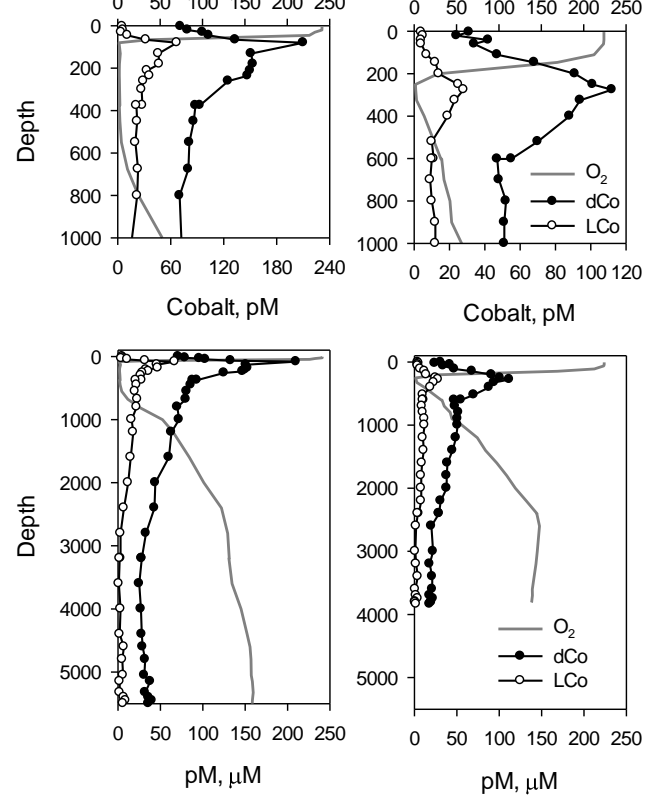

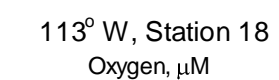
Oxygen, $\mu \mathrm{M}$
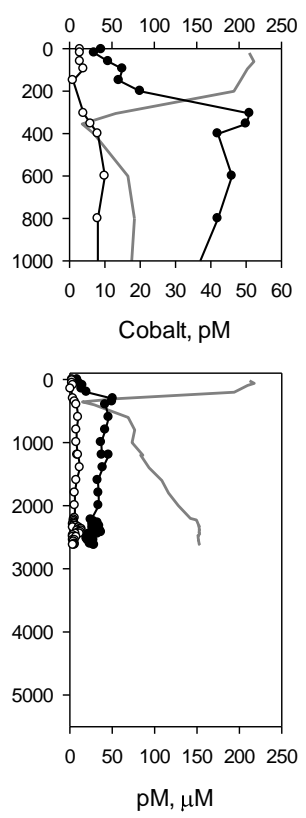

$120^{\circ} \mathrm{W}$, Station 23

Oxygen, $\mu \mathrm{M}$
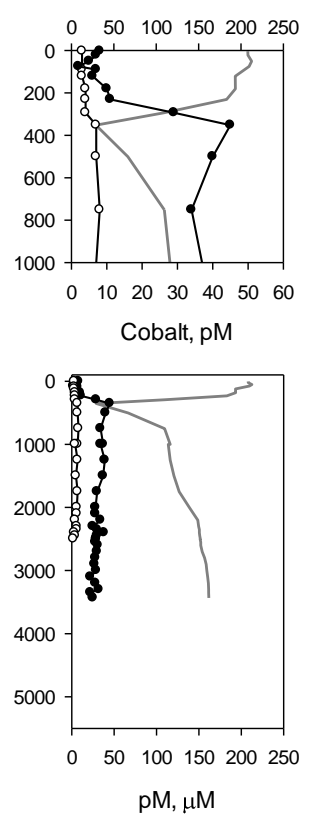

$152^{\circ} \mathrm{W}$, Station 36

Oxygen, $\mu \mathrm{M}$

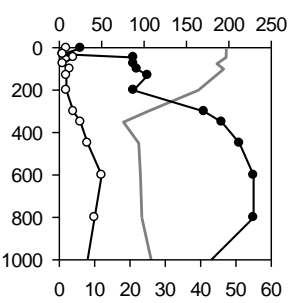

Cobalt, pM

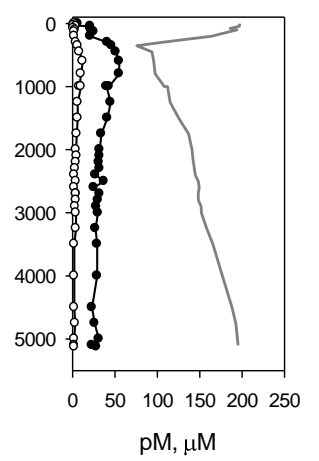

Figure 3. Profiles of dissolved cobalt (dCo, closed circles), labile dissolved cobalt (LCo, open circles), and $\mathrm{O}_{2}$ (grey lines) across the South Pacific. Upper panels show a 0-1000 m depth range; bottom panel show full profiles. dCo and LCo are highest close to the Peru margin (Station 1) and decrease westward. $\mathrm{O}_{2}$ follows the opposite trend. The small peak at $2400 \mathrm{~m}$ at Station 18 shows peak hydrothermal input from the East Pacific Rise. Note that the dCo and LCo scales in the upper panel are adjusted to highlight gradients and differ from the lower panels.

and $\mathrm{dMn}$ above background seawater measured at Station 18 (Resing et al., 2015).

dCo peaks in the mesopelagic zone, typically between 300 and $500 \mathrm{~m}$. Towards the Peru shelf, this maximum shoals and increases, following the position and intensity of the $\mathrm{OMZ}$ (defined here as $<20 \mu \mathrm{M} \mathrm{O}_{2}$ ). Although the OMZ is several hundred meters thick near the eastern margin (Fig. 3), dCo concentrations $>100 \mathrm{pM}$ are restricted to samples collected just below the oxycline. Despite this narrow depth range, $>100 \mathrm{pM}$ dCo extends as far as $100^{\circ} \mathrm{W}$. For all depths below $200 \mathrm{~m}$, dCo follows a negative linear relationship with $\mathrm{O}_{2}$ (Fig. 5a). Over the Peru shelf, maximum dCo was measured at the top of the OMZ and dCo decreased with depth (except for the shallowest and most shoreward Station 2). Only at the western edge of the section do dCo and $\mathrm{O}_{2}$ decouple: the dCo maximum at Station 36 is deeper (500-1000 m) than the oxygen minimum (300-500 m), seemingly independent of the influence of the South Pacific OMZ (Fig. 3).

All profiles show a surface or near-surface minimum that indicates biological uptake and export. As a result, dCo is well traced by dissolved phosphate, $\mathrm{PO}_{4}$, in the upper $200 \mathrm{~m}$ of the eastern tropical South Pacific (ETSP) (Fig. 5c). This relationship holds despite sharp transitions to high $\mathrm{dCo}$ in the oxycline near the Peru shelf. Upwelling of $\mathrm{O}_{2}$-depleted, $\mathrm{PO}_{4}$ rich waters contributes to high dCo in the surface ocean along the eastern margin with concentrations decreasing westward due to mixing and export. A secondary surface dCo maximum marked a cyclonic eddy sampled at $89^{\circ} \mathrm{W}$ (Station 9 , V. Sanial, personal communication, 2016), which appeared to transport a shelf-like dCo and LCo signature for the upper $300 \mathrm{~m}$ into the offshore OMZ (Fig. 6a, b). In the South Pacific gyre, dCo in the euphotic zone falls below $10 \mathrm{pM}$. While the lowest $\mathrm{PO}_{4}$ was found in low-salinity surface waters west of $140^{\circ} \mathrm{W}$, minimum dCo and deepest nutriclines corresponded to a southwestward excursion in the transect between stations 17-23 $\left(109-120^{\circ} \mathrm{W}\right)$, which were accompanied by high salinities (>36) associated with the eastern part of the subtropical gyre. In contrast to the deep, smooth dCo nutricline further to the east, stations at the western edge of the section (stations 32, 34, and 36) contained $20 \mathrm{pM}$ dCo until $\sim 50 \mathrm{~m}$ where concentrations decreased sharply surfaceward, resembling profiles in the North Atlantic (Fig. 3; Noble and Saito, 2016).

\subsection{Particulate cobalt}

The surface minimum in dCo is mirrored by a near-surface maximum in particulate cobalt (pCo) from biological uptake throughout the GP16 section. The distribution of $\mathrm{pCo}$ (Fig. 6c) resembles particulate phosphorus (pP), chlorophyll, and other indicators of phytoplankton biomass. Very high 

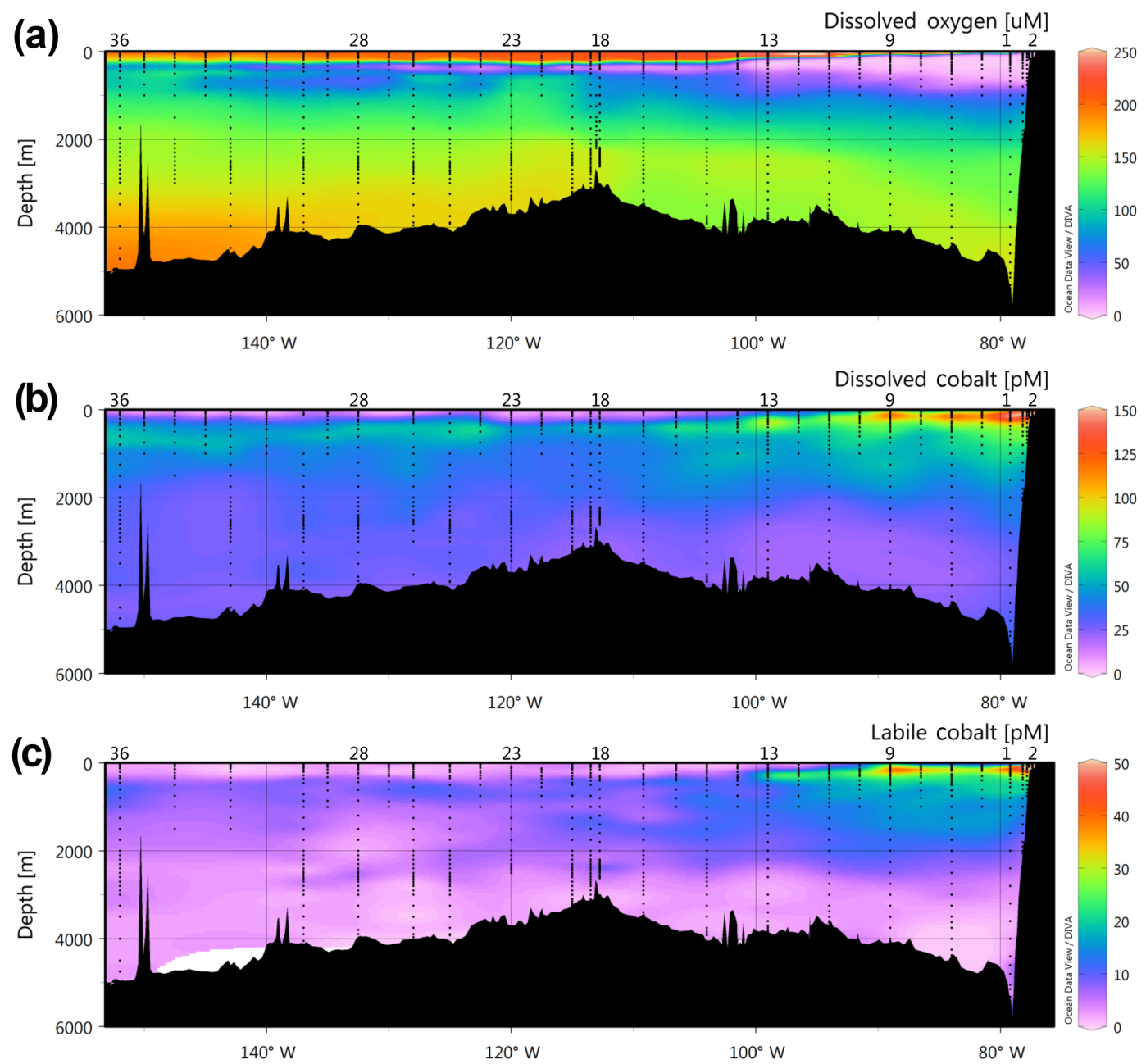

Figure 4. Dissolved oxygen (a), dissolved cobalt (b), and labile dissolved cobalt (c) sections along GP16, projected on a longitudinal axis. Note high dCo and LCo stem from the Peru margin and overlap with low $\mathrm{O}_{2}$. Interpolations were made using Ocean Data View with DIVA gridding, with negative gridded values suppressed. The signal-to-noise ratio was set to 15 for dissolved cobalt and labile dissolved cobalt. The signal-to-noise ratio for $\mathrm{O}_{2}$ was set to the default, 50 .

pCo $(>10 \mathrm{pM})$ was measured in the highly productive waters in the Peru upwelling ecosystem, while lower concentrations $(2-4 \mathrm{pM})$ were found in oligotrophic surface waters. West of $100^{\circ} \mathrm{W}$ in the ETSP, a secondary pCo maximum between 300 and $500 \mathrm{~m}$ overlaps with high particulate $\mathrm{Mn}$ $(\mathrm{pMn})$, reflecting Co incorporation into Mn oxides in oxygenated thermocline waters (Fig. 6c). Elevated pCo was also found at the top of the OMZ in the eastern half of the transect, corresponding with high dCo from remineralization. High $\mathrm{pP}$ and low $\mathrm{pMn}$ in these samples suggest that pCo may be present as biomass in anoxic bacterial and archaeal communities (Ohnemus et al., 2016), rather than incorporation into bacterial Mn oxides by co-oxidation.

\subsection{Labile dissolved cobalt}

dCo can be bound by extremely strong organic ligands that affect its reactivity (Ellwood and van den Berg, 2001; Saito and Moffett, 2001). These ligands may be composed of degradation products of the cobalt-bearing cofactor vitamin $\mathrm{B}_{12}$ and may be stabilized following oxidation of $\mathrm{Co}$ (II) to Co(III) (Baars and Croot, 2015). Unlike other metals such as $\mathrm{Fe}$, dCo bound to natural ligands is kinetically inert to ligand exchange (although some forms may still be bioavailable) and strong $\mathrm{Co}$ (II) ligands are not in excess of dCo, largely due to binding competition with nanomolar levels of labile nickel (Saito and Moffett, 2001; Saito et al., 2005). These properties can result in a significant fraction of labile dissolved cobalt (LCo) that can be measured without the UV oxidation procedure necessary to measure $\mathrm{dCo}$, especially in the mesopelagic zone (Noble et al., 2012). 
(a)

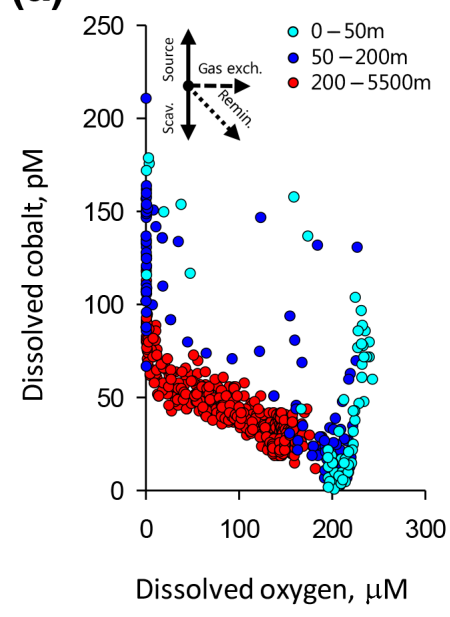

(b)

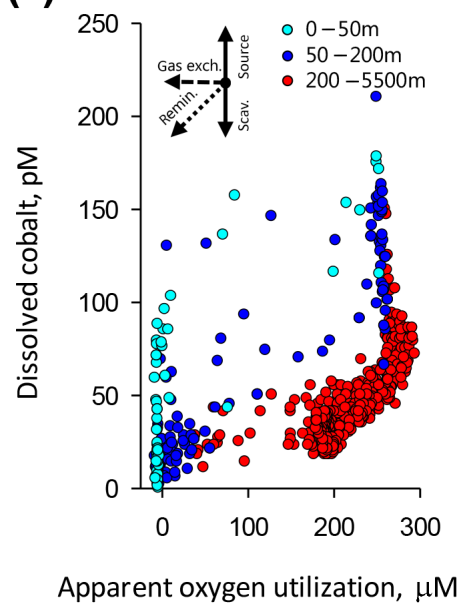

(c)

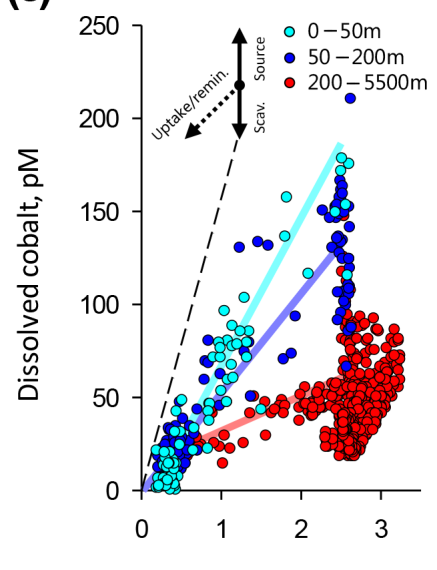

Dissolved phosphate, $\mu \mathrm{M}$

Figure 5. Coupling between dissolved cobalt with $\mathrm{O}_{2}$ (a), AOU (b), and $\mathrm{PO}_{4}$ (c). Below $200 \mathrm{~m}$ (red circles), dCo shows a decreasing linear trend with dissolved oxygen that is obscured upon conversion of $\mathrm{O}_{2}$ to apparent oxygen utilization, $\mathrm{AOU}$, and a weak relationship with $\mathrm{PO}_{4}$. In the surface ocean $\left(0-50 \mathrm{~m}\right.$, cyan circles), $\mathrm{dCo}$ and $\mathrm{PO}_{4}$ are strongly coupled but dCo shows no relationship with $\mathrm{O}_{2}$ or AOU. Samples from 50-200 $\mathrm{m}$ are plotted in blue. Trend lines in (c) show least-squares regressions of dCo and $\mathrm{PO}_{4}(0-50 \mathrm{~m}, \mathrm{cyan} ; 50-200 \mathrm{~m}$, blue; 200-1000 m, red). Also plotted is the median particulate $\mathrm{Co}: \mathrm{P}$ ratio for $0-50 \mathrm{~m}\left(146 \mu \mathrm{MM}^{-1}\right.$, dashed line). Major processes affecting these plots are described in vector legends.

In the ETSP, the distribution of LCo is similar to that of dCo (Figs. 3, 4, 6). Except for samples from the upper $50 \mathrm{~m}$, $\mathrm{dCo}$ and LCo form a linear relationship $\left(R^{2}=0.88\right)$ whose slope indicates that $\sim 33 \%$ of dCo is labile (Fig. 7a). Major exceptions are confined to the highly productive waters over the Peru shelf (stations 1-6) where LCo is much lower than expected. In these waters, LCo decreases in step with silicate (Fig. 7c). As in the North and South Atlantic (Noble et al., 2012; Noble and Saito, 2016), LCo is undetectable in the surface ocean outside of the waters influenced by upwelling (beyond $100^{\circ} \mathrm{W}$, Fig. 6b). The absence of LCo from the upper $300 \mathrm{~m}$ of the water column is deeper than corresponding gradients in the Atlantic, suggesting cobalt depletion is more intense in the South Pacific.

In the deep Pacific (more than $3000 \mathrm{~m}$ ), where dCo is low, LCo is undetectable. LCo remains low $(<15 \mathrm{pM})$ in the mesopelagic zone, except where the OMZ is most intense (Fig. 4). Within the OMZ, LCo maxima coincide with dCo maxima (stations 1-15), but further to the west these LCo maxima are much less pronounced and occur deeper than dCo maxima (Fig. 3). The LCo plume from the OMZ also extends deeper (below $2000 \mathrm{~m}$ ) than the corresponding dCo plume $(<2000 \mathrm{~m})$, suggesting that remineralization and scavenging affect these quantities in different ways. Slight secondary maxima between 1500 and $2000 \mathrm{~m}(10$ $15 \mathrm{pM})$ appear in the center of the section on $\sigma_{\theta}=27.7-$ $8 \mathrm{~kg} \mathrm{~m}^{-3}$ isopycnal layers (Fig. $4 \mathrm{c}, 105-115^{\circ} \mathrm{W}$ ), perhaps tracing transport of LCo remineralized in the eastern basin as these waters flow over the mid-ocean ridge.

\section{Discussion}

The most striking aspect of the dCo distribution in the ETSP is the very high concentrations present in the OMZ (Figs. 35). Similar distributions have been observed in both the North and South Atlantic, where $>100 \mathrm{pM}$ dCo plumes corresponded to low-oxygen waters underneath the Benguela and Mauritanian upwelling systems (Noble et al., 2012; Noble and Saito, 2016). In the North Pacific, profiles from the Costa Rica Dome (Ahlgren et al., 2014), the California margin (Biller and Bruland, 2013; Knauer et al., 1982), and the central Pacific along $155^{\circ} \mathrm{W}$ (Saito et al., 2014) support an OMZ-cobalt plume there as well. Based on measurements from these four OMZs, oxygen biogeochemistry seems to exert a major control on cobalt cycling throughout the oceans. It is interesting to note that the magnitude of the observed dCo plumes does not appear to scale with minimum $\mathrm{O}_{2}$ between Atlantic and Pacific OMZs. While minimum $\mathrm{O}_{2}$ in the Atlantic OMZs exceeds $20 \mu \mathrm{M}$, much of the ETSP is anoxic (Karstensen et al., 2008; Ulloa et al., 2012). Yet dCo in the ETSP occupies a similar 100-200 pM range reported for the North and South Atlantic OMZs (Noble et al., 2012; Noble and Saito, 2016). Clearly, other factors besides $\mathrm{O}_{2}$ alone contribute to large-scale plumes of dissolved cobalt in the oceans.

In the following, we describe the oceanographic processes that lead to elevated $\mathrm{dCo}$ and LCo concentrations in lowoxygen waters (Sect. 4.1). On the basin scale, the combined effects of remineralization and circulation link dCo with $\mathrm{O}_{2}$ throughout the water column in the ETSP (Sect. 4.1.1). The cobalt plume in the OMZ, however, is more than an extrapo- 

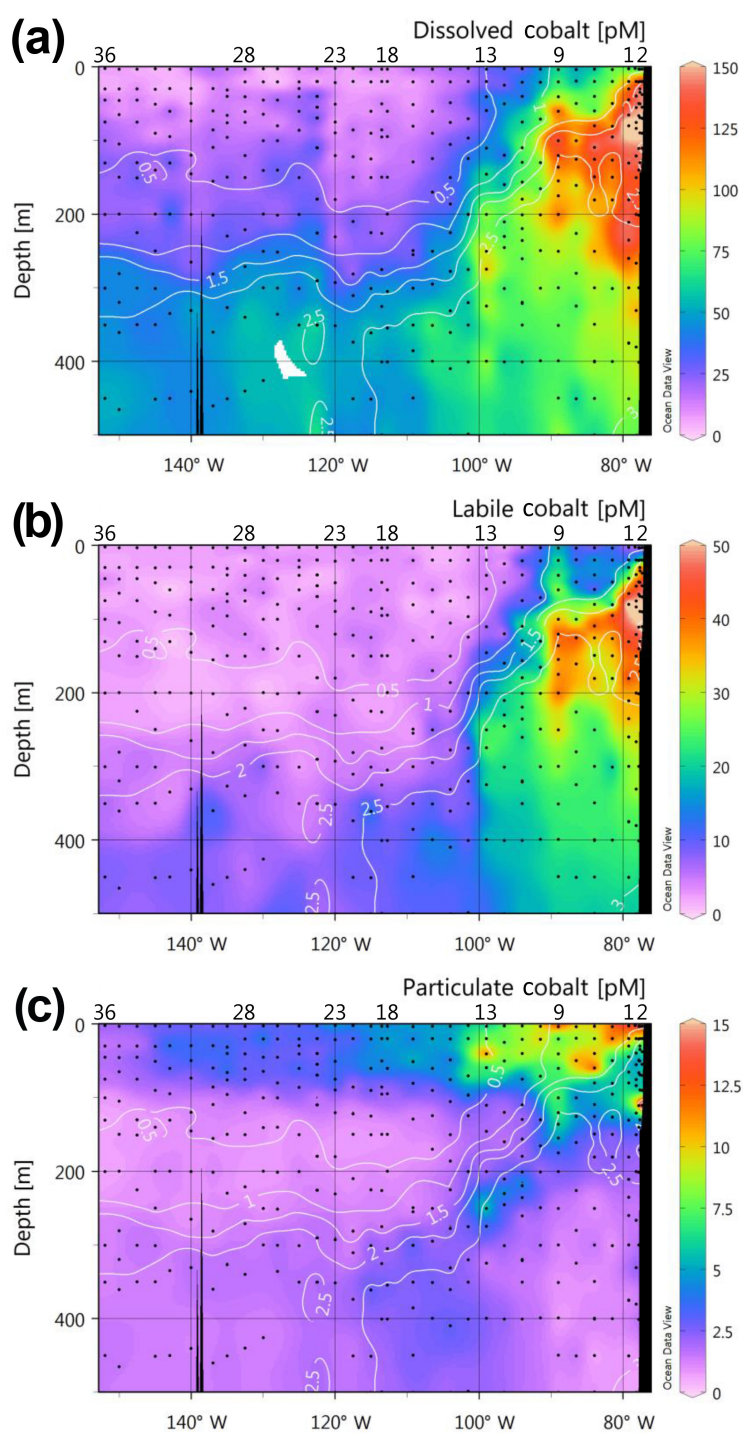

Figure 6. Dissolved cobalt (a), labile dissolved cobalt (b), and particulate cobalt (c) gradients in the upper $500 \mathrm{~m}$ of the ETSP. White lines in both panels show dissolved $\mathrm{PO}_{4}$ contours at $0.5 \mu \mathrm{M}$ increments. Interpolation was conducted using weight-averaged gridding with 40 and $46 \%$ length scales in the $x$ and $y$ directions, respectively.

lation of these mechanisms, requiring a large coastal source (Sect. 4.1.2), and suppression of dCo scavenging at very low $\mathrm{O}_{2}$ (Sect. 4.1.3). The mechanism, magnitude, and redox sensitivity of the coastal Co source are then examined in greater detail (Sect. 4.2). Finally, we highlight the scarcity of dCo-a critical micronutrient to phytoplankton - in the surface ocean of the South Pacific and the dependence of surface ocean dCo supply on coastal sources (Sect. 4.3).

\subsection{Processes generating the $\mathrm{OMZ}$ cobalt plume in the eastern South Pacific Ocean}

\subsubsection{Basin-scale remineralization and circulation couple dCo with $\mathrm{O}_{2}$}

In the ETSP, tight coupling between $\mathrm{dCo}$ and $\mathrm{O}_{2}$ is evident in the strong, inverse relationship that describes all samples below $200 \mathrm{~m}$ (Fig. 5a). In light of the nutrient-like dCo depletion in the surface of the ETSP and elsewhere (Fig. 6; Ahlgren et al., 2014; Dulaquais et al., 2014b; Noble et al., 2012), this negative correlation might be attributed to remineralization: $\mathrm{dCo}$ is returned to the dissolved phase from a sinking biogenic phase following respiration (i.e., $\mathrm{O}_{2}$ consumption). The slope of the $\mathrm{dCo}: \mathrm{O}_{2}$ line $\left(-0.33 \mu \mathrm{MM}^{-1}\right.$, $R^{2}=0.75$ for $200-5500 \mathrm{~m}$ ) would then represent the biological stoichiometry of the exported organic material in the ETSP. However, Co: $\mathrm{P}$ ratios in particulate material collected in the upper $50 \mathrm{~m}$ during GP16 indicate greater phytoplankton cobalt utilization (median $\mathrm{pCo}: \mathrm{pP}$ of $140 \mu \mathrm{M} \mathrm{M}^{-1} / 118 \mathrm{O}_{2}: \mathrm{P} \mathrm{MM}^{-1}=1.2 \mathrm{Co}: \mathrm{O}_{2} \mu \mathrm{M} \mathrm{M}^{-1}$; DeVries and Deutsch, 2014). If the $\mathrm{dCo}: \mathrm{O}_{2}$ trend is borne solely from remineralization, a greater slope would be expected, implying removal of $\mathrm{dCo}$ by scavenging. The linearity in the $\mathrm{dCo}: \mathrm{O}_{2}$ relationship is also not reproduced upon conversion of $\mathrm{O}_{2}$ to apparent oxygen utilization (AOU $=\mathrm{O}_{2}$, saturation $-\mathrm{O}_{2}$, measured, Fig. $5 \mathrm{~b}, R^{2}=0.49$ ), further suggesting that other factors besides remineralization (such as circulation and scavenging) shape the subsurface $\mathrm{dCo}$ distribution as well.

In the deep ocean, near-conservative mixing of low- $\mathrm{O}_{2}-$ high-dCo water masses with high- $\mathrm{O}_{2}$, low-dCo water masses probably contributes to the observed $\mathrm{dCo}: \mathrm{O}_{2}$ relationship. The enormous depth range (more than $5000 \mathrm{~m}$ ) described by the linear $\mathrm{dCo}: \mathrm{O}_{2}$ relationship contrasts with the nearexponential decrease in remineralization rates with depth (e.g., Karstensen et al., 2008). It is likely that deep Pacific circulation acts to spread signals of local dCo remineralization throughout the water column, aggregating a multitude of export stoichiometries and remineralization processes into a single, coherent relationship across the basin. LCo is undetectable below $\sim 2500 \mathrm{~m}$, and the shallower slope of the $\mathrm{LCo}: \mathrm{O}_{2}$ trend $\left(-0.11 \mu \mathrm{M} \mathrm{M}^{-1}, R^{2}=0.67\right.$, not shown) implies that the $\mathrm{dCo}: \mathrm{O}_{2}$ relationship is driven mostly by strongly complexed species, which are less vulnerable to co-oxidation by Mn-oxidizing bacteria in the water column (Moffett and Ho, 1996). Since the deep Pacific can be broadly regarded as a mixture of oxygenated circumpolar waters and OMZs (especially from the North Pacific), the linear $\mathrm{dCo}: \mathrm{O}_{2}$ relationship between 200 and $5500 \mathrm{~m}$ may reflect mixing of a $\mathrm{dCo}$ pool that is largely inert to losses by scavenging.

In the upper $200 \mathrm{~m}$, dCo is not well coupled with $\mathrm{O}_{2}$ and almost all samples fall above the line established by deeper samples (Fig. 5a). Near the South American margin, the 

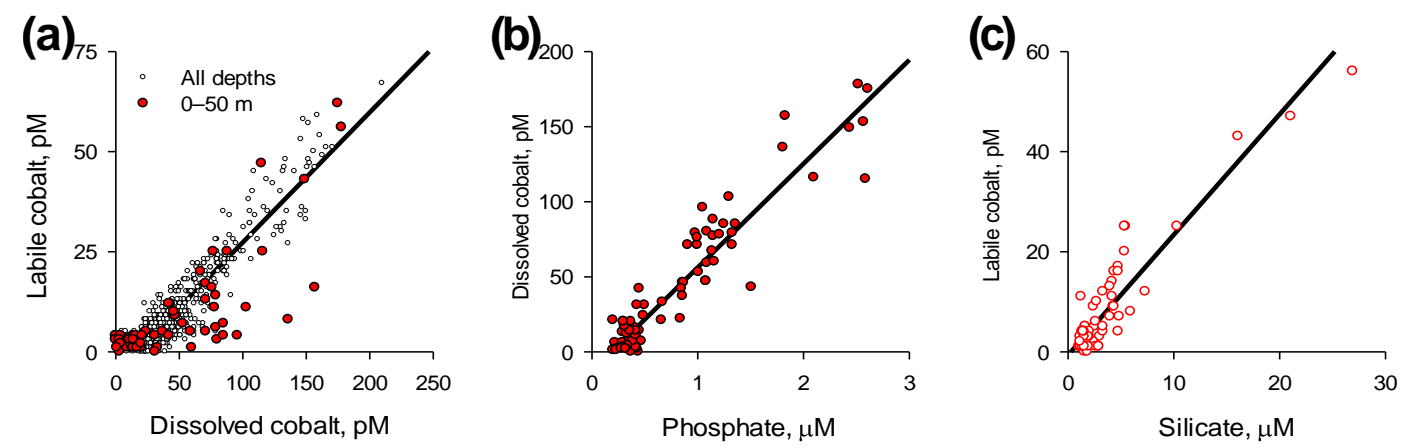

Figure 7. (a) The relationship between dissolved cobalt (dCo) and labile cobalt (LCo) in the South Pacific. LCo increases linearly with dCo with a slope of 0.33 (white dots, $R^{2}=0.88$ ), except for the upper $50 \mathrm{~m}$ (red dots), where samples fall below this trend due to preferential depletion of LCo by phytoplankton. (b) In the $0-50 \mathrm{~m}$ range, dCo strongly correlates with phosphate $\left(R^{2}=0.89\right)$. (c) LCo is preferentially removed from surface waters $(0-50 \mathrm{~m})$ and tracks silicate $\left(R^{2}=0.90\right)$.

dCo maximum in the upper $\mathrm{OMZ}$ is more than twice the $\mathrm{dCo}$ concentration expected by extrapolation of the basinscale $\mathrm{dCo}: \mathrm{O}_{2}$ relationship to the $0 \mu \mathrm{M} \mathrm{O}_{2}$ intercept $(77 \mathrm{pM}$, Fig. 5a). The similarity of dCo profiles to profiles of excess $\mathrm{N}_{2}$ from denitrification from this region (e.g., Chang et al., 2010) implies that both the dCo maximum in the OMZ and its decrease with depth are driven by factors that also affect nitrogen loss: namely in situ remineralization of sinking biogenic particles and lateral transport of coastal waters that experience high rates of denitrification and are also rich in $\mathrm{dCo}$ (DeVries et al., 2012).

\subsubsection{Distinct surface and mesopelagic Co : $P$ relationships}

In the upper ocean (0-200 m), dCo is linearly related to $\mathrm{PO}_{4}$ (Fig. 5c), indicating that the processes controlling $\mathrm{PO}_{4}$ in the surface - upwelling, mixing, biological uptake and export - are the main drivers of $\mathrm{dCo}$ as well. In the upper $50 \mathrm{~m}$, the $\mathrm{dCo}: \mathrm{PO}_{4}$ slope $\left(69 \mu \mathrm{M}: \mathrm{M}, R^{2}=0.89\right.$, Fig. $\left.7 \mathrm{~b}\right)$ may describe export stoichiometry throughout the eastern Pacific. That the surface $\mathrm{dCo}: \mathrm{PO}_{4}$ slope intercepts the highest $\mathrm{dCo}$ concentrations (below the $50 \mathrm{~m}$ depth range of the regression, Fig. 5c, cyan line) indicates that new cobalt sourced from the shelf is rapidly incorporated into the biological cycle and that the capacity for phytoplankton Co uptake is not overwhelmed by the order-of-magnitude higher dCo in coastal waters relative to the open ocean. Culture experiments with model diatoms and coccolithophores demonstrate this capacity (Shaked et al., 2006; Sunda and Huntsman, 1995; Yee and Morel, 1996), deploying Co to zinc enzymes to maintain activity when $\mathrm{Zn}$ becomes scarce. When $\mathrm{Zn}$ is limiting, Co quotas, as observed in open-ocean phytoplankton, are 10100 times greater than Co quotas when $\mathrm{Zn}$ is replete (Sunda and Huntsman, 1992; Twining and Baines, 2013). Therefore, minor substitution of $\mathrm{Zn}$ quotas by Co $(\sim 10 \%)$ can double cellular Co levels in eukaryotes, resulting in nearly complete uptake of dCo from the surface ocean.
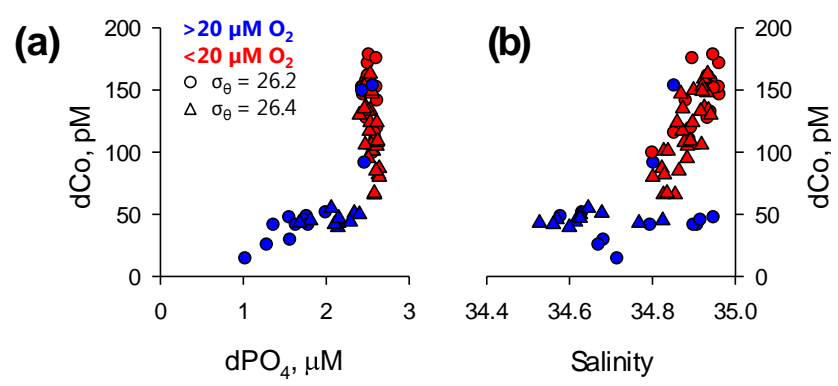

Figure 8. Transition in dCo cycling at the OMZ boundary in the upper South Pacific thermocline. (a) Isopycnal windows centered at $\sigma_{\theta}=26.2 \pm 0.1 \mathrm{~kg} \mathrm{~m}^{-3}$ (circles) and $\sigma_{\theta}=26.4 \pm 0.1 \mathrm{~kg} \mathrm{~m}^{-3}$ (triangles) show $\mathrm{PO}_{4}$-coupled cycling in oxygenated waters (blue) but not in $\mathrm{OMZ}$ waters with $<20 \mu \mathrm{MO}_{2}$ (red). (b) In the $\mathrm{OMZ}$, dCo follows salinity, indicating mixing between a high dCo endmember at a salinity of 35.0 and a fresher water mass that is low in dCo.

A separate nutrient-like $\mathrm{dCo}: \mathrm{PO}_{4}$ trend arises from gradients of both elements in the open-ocean nutricline (Fig. 5c). The slope of the mesopelagic trend $(16 \mu \mathrm{M}: \mathrm{M}$, for 200 $1000 \mathrm{~m}$, red line in Fig. 5c) is much less than that measured for the upper $50 \mathrm{~m}(69 \mu \mathrm{M}: \mathrm{M}$, cyan line). Due to considerable preformed $\mathrm{PO}_{4}$ in deep waters, as well as elevated $\mathrm{dCo}: \mathrm{PO}_{4}$ ratios in the OMZ, the mesopelagic $\mathrm{dCo}: \mathrm{PO}_{4}$ regression is less robust than in the surface $\left(R^{2}=0.21\right)$, though the slope does reflect $\mathrm{dCo}$ and $\mathrm{PO}_{4}$ covariation in this depth range when $\mathrm{PO}_{4}$ is $<2 \mu \mathrm{M}$ (Fig. 5c, red line). Regardless, there seems to be a fundamental mismatch between $\mathrm{dCo}: \mathrm{PO}_{4}$ from the upper water column $(0-200 \mathrm{~m})$ and that observed at greater depth $(200-1000 \mathrm{~m})$.

In the eastern margin, the surface and mesopelagic $\mathrm{dCo}: \mathrm{PO}_{4}$ vectors are joined at $2.6 \mu \mathrm{MPO}_{4}$ by a near-vertical line that makes the $\mathrm{dCo}: \mathrm{PO}_{4}$ domain triangular. Interpretation of this line depends largely on its perceived direction: a downward vector can be a fingerprint of scavenging, while an upward vector describes a cobalt source (Noble 
et al., 2008; Saito et al., 2010). This ambiguity is clarified by examining $\mathrm{dCo}: \mathrm{PO}_{4}$ gradients within isopycnal surfaces, which strongly indicate a source at low $\mathrm{O}_{2}$. In the ETSP, $\sigma_{\theta}$ 26.2 and 26.4 isopycnals host the upper OMZ and the oxygenated thermocline waters west of $100^{\circ} \mathrm{W}$. Water masses on these surfaces can be distinguished on the basis of salinity; from the GP16 dataset, mixing between salty and deoxygenated equatorial subsurface waters (ESSW or $13{ }^{\circ} \mathrm{C}$ water) with fresher, ventilated subantarctic waters is apparent (Fiedler and Talley, 2006; Toggweiler et al., 1991). Oxygenated waters on $\sigma_{\theta}=26.2$ and 26.4 show a tight coupling between $\mathrm{dCo}$ and $\mathrm{PO}_{4}$ from remineralization of both elements (Fig. 8a). For samples with $<20 \mu \mathrm{M} \mathrm{O}_{2}$, however, deviation from the oxic $\mathrm{dCo}: \mathrm{PO}_{4}$ trend is always positive, indicating a dCo source within the OMZ. When oxygen is low, dCo follows salinity (Fig. 8b). Mixing of high-salinity (34.935.0), high-dCo ESSW from the northeast with low-salinity, low-dCo subantarctic waters explains the dCo: salinity covariation on these isopycnal surfaces. While ESSW is fed by the equatorial undercurrent (EUC), which originates near Papua New Guinea and transports a large Fe and Al source eastward (Slemons et al., 2010), it is low in dCo (as measured at $155^{\circ} \mathrm{W}$; Saito et al., 2014). When the EUC bifurcates near the Galapagos, it mixes with coastal waters north and south of the equator (Fiedler and Talley, 2006; Stramma et al., 2010), where its high dCo signature is likely acquired.

\subsubsection{Suppression of cobalt scavenging in the OMZ}

The isopycnal $\mathrm{dCo}$ : salinity relationship implies that cobalt scavenging in the OMZ is low (Fig. 8b). This is not surprising given the slower rates of $\mathrm{MnO}_{2}$ formation at low $\mathrm{O}_{2}$ (Johnson et al., 1996; von Langen et al., 1997) and very low particulate Mn measured in the ETSP OMZ (Ohnemus et al., 2016). In the OMZ, both $\mathrm{pCo}: \mathrm{pP}$ and $\mathrm{pMn}: \mathrm{pP}$ ratios are consistent with micronutrient use by microbial communities and resemble biomass collected in the euphotic zone during GP16 (Co:P $=0.5-4 \times 10^{-4} \mathrm{M} \mathrm{M}^{-1}$, $\mathrm{Mn}: \mathrm{P} \sim 10^{-3} \mathrm{MM}^{-1}$; Fig. 9, pink and cyan lines). These low, biomass-like $\mathrm{pCo}: \mathrm{pP}$ and $\mathrm{pMn}: \mathrm{pP}$ signatures in the ETSP OMZ are consistent with thermodynamic and kinetic barriers to $\mathrm{Mn}$ oxidation at very low $\mathrm{O}_{2}$ (Ohnemus et al., 2016).

Crossing the anoxic-oxic transition at $100^{\circ} \mathrm{W}$ in the thermocline $\left(\sigma_{\theta} 26.2-27.0\right.$, centered at $300 \mathrm{~m}$ ) results in a factor of 10 higher pMn concentrations and implies a redox threshold to Mn oxidation in the mesopelagic zone (Fig. 9, blue circles). Heterotrophic Mn-oxidizing bacteria are known to incorporate Co by enzymatic co-oxidation into the $\mathrm{Mn}$ oxide lattice and are prevalent throughout the water column (Cowen and Bruland, 1985; Moffett and Ho, 1996). While particulate Co profiles in the ETSP have a near-surface maximum from biological uptake (Fig. 6c), pCo attenuates much less with depth than $\mathrm{pP}$ in oxic thermocline waters. Very high $\mathrm{pCo}$ : pP ratios (up to $10^{-3} \mathrm{MM}^{-1}$ ) are found in the oxy-

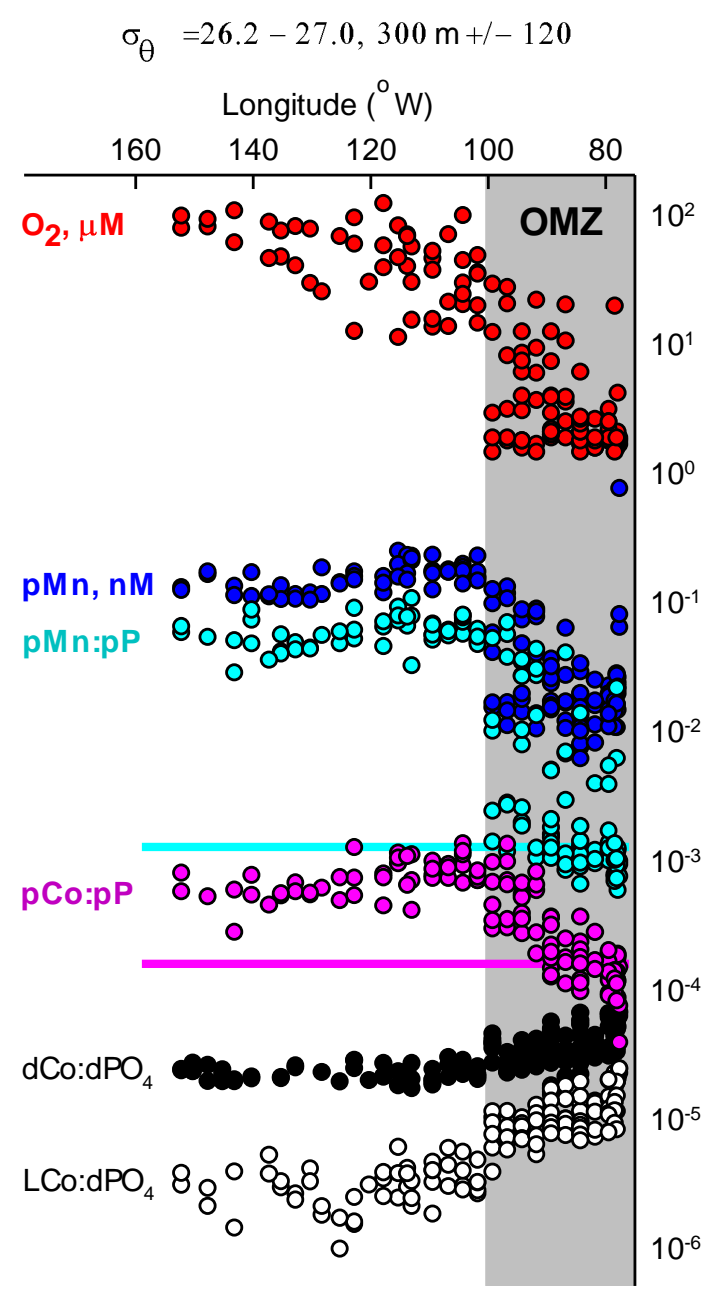

Figure 9. Redox control of $\mathrm{Co}$ and $\mathrm{Mn}$ scavenging. Within mesopelagic waters $\left(\sigma_{\theta}=26.2-27.0 \mathrm{~kg} \mathrm{~m}^{-3}\right.$, mean depth of $300 \mathrm{~m}$ ), high $\mathrm{O}_{2}$ in ventilating water masses results in a sharp redox boundary at the edge of the OMZ (red circles, scale in $\mu \mathrm{M}$ ). Particulate $\mathrm{Mn}(\mathrm{pMn})$ increases across the oxic-anoxic boundary at $100^{\circ} \mathrm{W}$ (blue circles, in $\mathrm{nM}$ ) and implies stabilization of $\mathrm{Mn}$ oxides. Both $\mathrm{pMn}: \mathrm{pP}$ and $\mathrm{pCo}: \mathrm{pP}$ (cyan and pink circles, respectively; units are $\mathrm{MM}^{-1}$ ) increase across the OMZ boundary, exceeding predicted values from remineralization of biogenic material from the surface ocean $\left(1.26 \times 10^{-3}\right.$ mean $\mathrm{pMn}: \mathrm{pP}$ and $1.57 \times 10^{-4} \mathrm{pCo}: \mathrm{pP}$ for $0-50 \mathrm{~m}\left(\mathrm{M} \mathrm{M}^{-1}\right)$, cyan and pink lines, respectively). Dissolved-phase $\mathrm{dCo}^{\mathrm{d}} \mathrm{dPO}_{4}$ (black circles) and $\mathrm{LCo}: \mathrm{PO}_{4}$ (white circles) also decrease west of the OMZ boundary and show scavenging of $\mathrm{dCo}$ and LCo in the mesopelagic zone (units are $\mathrm{MM}^{-1}$ ).

genated thermocline but not in the OMZ (Fig. 9, pink circles). The coincidence of high $\mathrm{pCo}: \mathrm{pP}$ and high $\mathrm{pMn}$ throughout the mesopelagic zone is consistent with pCo being present in an authigenic Mn-oxide phase, marking an important transition between nutrient-like cobalt cycling in the surface ocean (where pCo is almost entirely biogenic) to Mn-oxide-driven scavenging at depth. 
The stimulation of cobalt scavenging across the anoxicoxic transition at $100^{\circ} \mathrm{W}$ was also reflected in a sharp decrease in $\mathrm{LCo}: \mathrm{PO}_{4}$ as scavenging removed LCo from the water column (Fig. 9, black circles). Indeed, the same oxygenated thermocline samples with high $\mathrm{pMn}$ and $\mathrm{pCo}: \mathrm{pP}$ are responsible for the gradual slope in $\mathrm{dCo}: \mathrm{PO}_{4}$ space $\left(16 \mu \mathrm{M} \mathrm{M}^{-1}\right.$, Fig. $5 \mathrm{c}$, red line). The offset between high surface and low mesopelagic $\mathrm{dCo}: \mathrm{PO}_{4}$ is mirrored by the lower surface and higher mesopelagic $\mathrm{pCo}: \mathrm{pP}$. While scavenging is often presumed to draw chiefly on metals in the dissolved phase, the heterotrophic nature of Mn-oxidizing bacteria and their abundance in sediment traps hint that Mn-oxidizing bacteria may access biogenic metal pools within sinking particles (Cowen and Bruland, 1985). In such a case, pCo may be shunted directly from a biogenic to an authigenic phase without being truly remineralized, preventing the equal return of dCo at depth relative to that exported from the surface, as documented here by the disparity between deep and shallow dCo: $\mathrm{PO}_{4}$ slopes (Fig. 5c). An important consequence of mesopelagic scavenging is that ventilation of these waters by upwelling without an exogenous source (e.g., the continental margin) would create conditions whereby $\mathrm{dCo}$, relative to $\mathrm{PO}_{4}$, is not supplied to the same extent that it is presently utilized and exported. Because these scavenged waters are relatively shallow and have short ventilation ages (Fiedler and Talley, 2006), fluxes of cobalt to the South Pacific from margin sources must be large in order to balance these scavenging losses.

\subsection{A major cobalt source from the Peruvian margin}

\subsubsection{Water column signatures of a dCo source}

The strong covariation between high dCo and low $\mathrm{O}_{2}$ in the ETSP and the intersection of the OMZ with the South American margin suggest that the continental shelf may be an important cobalt source. Sections from the North and South Atlantic (Noble et al., 2012; Noble and Saito, 2016) and profiles from the North Pacific (Ahlgren et al., 2014; Knauer et al., 1982) have resulted in similar assertions, but the coincidence of high phytoplankton productivity along eastern margins also imprints signals from elevated remineralization. This is certainly the case for the ETSP, where stations 2 and 3 on the Peru shelf featured more than $1.5 \mu \mathrm{g}$ chlorophyll $\mathrm{L}^{-1}$ in the euphotic layer and more than $4 \mu \mathrm{M}$ nitrite throughout the OMZ from intensified anoxic remineralization. As a result, the dCo profile in Peru shelf waters strongly resembles $\mathrm{PO}_{4}$ and other nutrients above the oxycline (Fig. 10). Unlike $\mathrm{PO}_{4}$, however, these shelf stations show a dCo maximum at the oxycline and decreasing concentrations with depth that more strongly resemble the Mn profile (Fig. 10), implying that additional processes contribute to the dCo profile over the shelf.

Positive correlations between $\mathrm{dCo}$, LCo, and $\mathrm{dMn}$ within the OMZ on the Peru shelf reflect a shared source (Fig. 11).
The slope of the LCo: $\mathrm{dMn}$ relationship $\left(18 \pm 2 \mathrm{mM} \mathrm{M}^{-1}\right.$ $\left.R^{2}=0.76\right)$ is nearly identical to that in the upper continental crust and andesite (21-26 $\mathrm{mM} \mathrm{M}^{-1}$, McLennan, 2001; Taylor and McLennan, 1995), matching expectations that mineral dissolution should provide labile Co. However, the steeper slope for the $\mathrm{dCo}: \mathrm{dMn}$ relationship (42 $\left.\pm 5 \mathrm{mM} \mathrm{M}^{-1}, R^{2}=0.67\right)$ exceeds crustal endmembers. Addition of a second, Co-enriched component is needed to explain the observed relationship. Given the massive productivity over the Peru shelf, biological export and remineralization of $\mathrm{dCo}$ and $\mathrm{dMn}$ in the $\mathrm{OMZ}$ are a reasonable cause for the high Co: Mn ratio in the shelf OMZ. From particulate material in the upper $40 \mathrm{~m}$ of shelf stations (1-5), the average Co: Mn ratio in local biomass is between 100 and $110 \mathrm{mM} \mathrm{M}^{-1}$ (median and mean), roughly 5 times higher than in continental crust and falling within the range reported for single-cell analysis of phytoplankton cells from other regions (70-400 $\mathrm{mM} \mathrm{M}^{-1}$, Twining and Baines, 2013). The combination, then, of a high biotic $\mathrm{Co}: \mathrm{Mn}$ ratio and a lower ratio from a sedimentary source can produce the slope observed in the water column but requires remineralized dCo to be chiefly ligand-bound in order to preserve the near-crustal LCo: Mn slope. The higher Co: $\mathrm{Mn}$ ratio in biomass relative to their shared sedimentary source also results in a nutrient trap that returns upwelled dCo to the OMZ more efficiently than $\mathrm{dMn}$ and implies that input of dCo from the shelf is rapidly followed by biological utilization, evident in the immediate transition from a dMn-like profile below the oxycline to a $\mathrm{PO}_{4}$-like profile above it (Fig. 10).

Water column observations of a large dCo source are also mirrored in the depleted Co contents of continental shelf sediments along the Peru margin. A survey of continental shelf sediments underlying the Peru OMZ found low $\mathrm{Co} / \mathrm{Al}$ ratios $\left(1.2 \pm 0.3 \times 10^{-4} \mathrm{gg}^{-1}\right.$, Böning et al., 2004) relative to andesitic and upper continental crusts (2.63 and $2.11 \times 10^{-4} \mathrm{~g} \mathrm{~g}^{-1}$, respectively, McLennan, 2001; Taylor and McLennan, 1995), requiring that about half of the Co delivered to the continental shelf from crustal sources dissolved prior to long-term burial on the shelf. The only other element to have a similar depletion was Mn, which covaried with Co across all samples in the Böning et al. (2004) study, consistent with the release of both metals by reductive dissolution. Yet the exact mechanism for dCo release is unclear: mass balance calculations for $\mathrm{Mn}$ indicate that diffusive fluxes from sediment porewaters on the Peru shelf are much too slow to account for solid-phase $\mathrm{Mn} / \mathrm{Al}$ deficits that accumulate in the sediment column (Scholz et al., 2011). Therefore, most $\mathrm{Mn}$ is released prior to sedimentation on the margin, either by dissolving directly in the water column or through upstream release in estuaries. Since Co covaries with $\mathrm{Mn}$ in both dissolved and sediment phases (Fig. 11; Böning et al., 2004), the ultimate source of the dCo plume in the Peruvian OMZ may not be generated by diffusion from margin sediments either. 

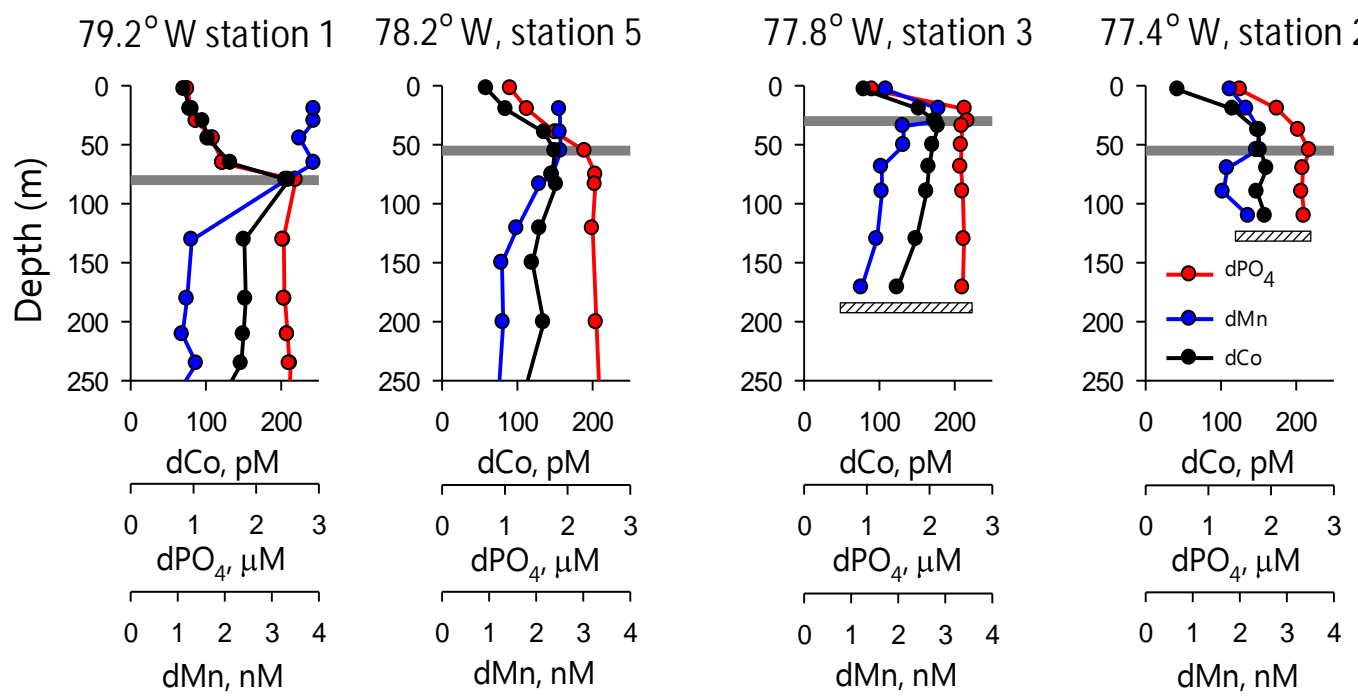

Figure 10. Profiles of dissolved cobalt (dCo, black), $\mathrm{PO}_{4}$ (red), and dMn (blue) over the Peru shelf at $12^{\circ} \mathrm{S}$. The oxycline (grey bar, defined by the first sample where $\mathrm{O}_{2}<10 \mu \mathrm{M}$ ) marks the transition between the OMZ and oxygenated surface waters. Station 2 is the closest to the coast. Note the similarity between $\mathrm{dCo}$ and $\mathrm{PO}_{4}$ above the oxycline and the transition to a dMn-like profile beneath.

Table 2. Co / Al ratios in sediments from different redox regimes.

\begin{tabular}{|c|c|c|c|}
\hline Location & \multicolumn{2}{|c|}{$\mathrm{Co} / \mathrm{Al} \times 10^{-4}\left(\mathrm{~g} \mathrm{~g}^{-1}\right)$} & Reference \\
\hline \multicolumn{4}{|l|}{ Crust } \\
\hline Upper continental crust & 2.11 & & McLennan (2001) \\
\hline Andesitic crust & 2.63 & & Taylor and McLennan (1995) \\
\hline \multicolumn{4}{|l|}{ Eastern boundary sediments } \\
\hline Peru upwelling sediments & $1.2 \pm 0.3$ & $9-14^{\circ} \mathrm{S}$ & Böning et al. (2004) \\
\hline Chile upwelling sediments & $1.3 \pm 0.1$ & $36^{\circ} \mathrm{S}$ & Böning et al. (2009) \\
\hline Gulf of California & 1.4 & $22-30^{\circ} \mathrm{N}$ & Brumsack (1989) \\
\hline Namibian shelf & $1.0 \pm 0.3$ & $17-25^{\circ} \mathrm{S}$, "terrigenous" & Bremner and Willis (1993) \\
\hline \multicolumn{4}{|l|}{ Sulfidic sediments } \\
\hline Namibian diatom belt & $2.9 \pm 0.7$ & Near Walvis Bay, $22.5^{\circ} \mathrm{S}$ & Borchers et al. (2005) \\
\hline Black Sea & $3.8-6.2$ & & Brumsack (2006) \\
\hline \multicolumn{4}{|l|}{ Western boundary sediments } \\
\hline Papua New Guinea & 2.3 & $8^{\circ} \mathrm{S}$, Gulf of Papua & Alongi et al. (1996) \\
\hline Pearl River delta & $2.2 \pm 0.4$ & $22^{\circ} \mathrm{N},(10-0 \mathrm{ka})$ & Hu et al. (2013) \\
\hline South China Sea shelf slope & $2.1 \pm 0.2$ & $20^{\circ} \mathrm{N}, 2037 \mathrm{~m}(14-0 \mathrm{ka})$ & Hu et al. (2012) \\
\hline \multicolumn{4}{|l|}{ Deep ocean sediments } \\
\hline South Pacific gyre & $35(2.9-101)$ & $22-32^{\circ} \mathrm{S}, 100-0 \mathrm{Ma}$ & Dunlea et al. (2015) \\
\hline Pelagic Pacific & $17(2-58)$ & $50^{\circ} \mathrm{N}-20^{\circ} \mathrm{S}$ & Goldberg and Arrhenius (1958) \\
\hline
\end{tabular}

\subsubsection{Potential redox sensitivity of coastal cobalt sources}

The $\mathrm{Co} / \mathrm{Al}$ ratio in buried sediments on the continental shelf can provide a coarse measure of how much Co has been released to the ocean. Subcrustal Co / Al ratios in Peruvian sediments between 9 and $14^{\circ} \mathrm{S}$ (Böning et al., 2004) match similar measurements in Chilean OMZ sediments at $36^{\circ} \mathrm{S}$ (Table 2, $\mathrm{Co} / \mathrm{Al}=1.3 \times 10^{-4} \mathrm{~g} \mathrm{~g}^{-1}$, Böning et al.,
2009) and the Gulf of California $\left(1.4 \times 10^{-4} \mathrm{~g} \mathrm{~g}^{-1}\right.$, Brumsack, 1989). The deficit between these values and continental crust $\left(2.11 \times 10^{-4} \mathrm{~g} \mathrm{~g}^{-1}\right)$ implies that dissolution of crustal materials along the eastern margin provides a large source of $\mathrm{dCo}$ and LCo to the Pacific. In the absence of large hydrothermal inputs (see Sect. 4.2.5; Swanner et al., 2014), burial of Co-depleted sediments on the margin is needed to balance extremely high $\mathrm{Co} / \mathrm{Al}$ ratios in Pacific pelagic sediments, 


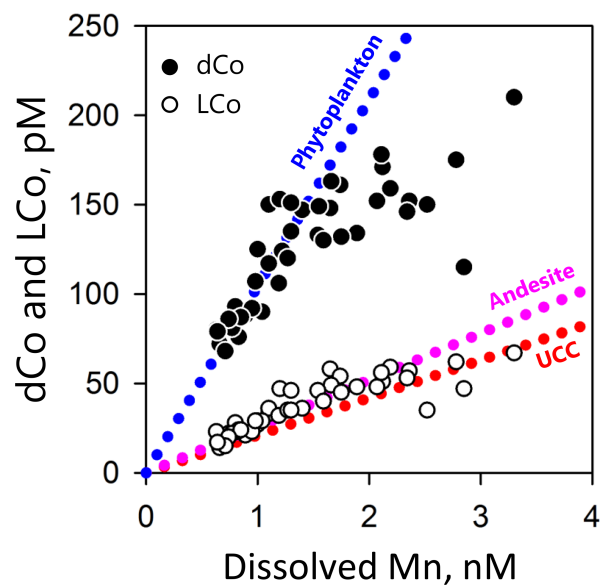

Figure 11. Cobalt and $\mathrm{Mn}$ in the Peru shelf OMZ (GP16 stations $\left.1-5, \mathrm{O}_{2}<20 \mathrm{uM}\right)$. Dissolved cobalt (dCo, closed circled) and labile cobalt (LCo, white) follow positive linear relationships with $\mathrm{dMn}$. The LCo slope $\left(18 \mathrm{mMM}^{-1}\right)$ approximates the Co: Mn ratio in the upper continental crust and andesite (red and pink lines, 21 and $26 \mathrm{mM} \mathrm{M}^{-1}$, respectively), suggesting that it derives from a crustal source. The mean $\mathrm{pCo}: \mathrm{pMn}$ ratio from phytoplanktondominated particles collected in the upper $40 \mathrm{~m}$ over the shelf (blue line, $\left.105 \mathrm{mM} \mathrm{M}^{-1}\right)$ is greater than $\mathrm{dCo}: \mathrm{dMn}$ slope $\left(42 \mathrm{mM} \mathrm{M}^{-1}\right)$, indicating that $\mathrm{dCo}$ and $\mathrm{dMn}$ concentrations in the Peru shelf $\mathrm{OMZ}$ represent a combination of biomass remineralization and sedimentary input.

which collect Co scavenged from the water column (e.g., Dunlea et al., 2015; Goldberg and Arrhenius, 1958).

In contrast to depleted Co along the South American shelf, the Co / Al ratio in shelf sediments from the western margin of the Pacific appears crustal (Table 2). Holocene records from the Pearl River delta and shelf slope in the South China Sea $\sim 20^{\circ} \mathrm{N}$ (Hu et al., 2012, 2013) show mean $\mathrm{Co} / \mathrm{Al}$ ratios of 2.2 and $2.1 \times 10^{-4} \mathrm{~g} \mathrm{~g}^{-1}$, respectively, similar to sediments from the Gulf of Papua at $9^{\circ} \mathrm{S}\left(2.3 \times 10^{-4} \mathrm{~g} \mathrm{~g}^{-1}\right.$, Alongi et al., 1996). Crustal Co / $\mathrm{Al}$ in these sedimentary systems implies that most of the Co provided from fluvial sediment delivery either does not dissolve or is quickly reburied by water column Mn oxidation, rates of which can be very high in estuaries and coastal seas (Moffett and Ho, 1996; Moffett, 1994; Sunda and Huntsman, 1987; Sunda and Huntsman, 1990).

It is likely that oxidizing conditions in the water column and surface sediments limit the release of cobalt on the western margin, leading to crustal Co / $\mathrm{Al}$ ratios in shelf sediments, while suboxic conditions on the eastern margin mobilize Co, evident in depleted $\mathrm{Co} / \mathrm{Al}$ ratios observed there. Although sedimentary anoxia releases Co bound in $\mathrm{Mn}$ oxides, even a thin layer of $\mathrm{O}_{2}$ penetration into sediments results in a near-zero diffusive flux into the water column (Heggie and Lewis, 1984). Indeed, El Niño-driven oxygenation events on the Peru shelf are associated with deposition of Mn oxides in shallow sediments (Scholz et al., 2011). Bot- tom water deoxygenation restores Co fluxes to the water column (Johnson et al., 1988; Sundby et al., 1986), but Co is also incorporated into sulfide minerals, analogous to the "Goldilocks" mechanism for benthic Fe release where flux is maximized when redox conditions are low enough to promote oxide dissolution but still high enough to avoid pyrite burial (into which cobalt is incorporated; Morse and Luther, 1999; Scholz et al., 2014). Cobalt burial in pyrite is evident in the high Co / Al content of Black Sea sediments (Brumsack, 2006) and sulfide-rich pockets of Namibian sediments near Walvis Bay $\left(2.9 \times 10^{-4} \mathrm{~g} \mathrm{~g}^{-1}\right.$, Borchers et al., 2005), despite more widespread Co depletion in suboxic (but not sulfidic) terrigenous sediments underneath the Benguela upwelling region (Bremner and Willis, 1993). Prevailing suboxic conditions along the Namibian coast ultimately lead to an extensive dCo plume that reaches across the South Atlantic basin (Noble et al., 2012). Similarly, depleted sedimentary $\mathrm{Co} / \mathrm{Al}$ on the Peruvian margin and high dCo in the water column perhaps reflect sustained anoxia that, in the present, is unlikely outside the domain of OMZs.

Altogether, the accumulating evidence that the oceans' major OMZs harbor dCo plumes (Noble et al., 2012; Alhgren et al., 2014; Noble et al., 2016) indicates a strong chemical connection between the efficiency of dCo sources and local redox conditions where these OMZs interact with the continental margin. While reductive dissolution is the most likely mechanism at play, whether this process predominantly occurs in estuaries, the OMZ water column, or margin sediments is presently unclear but will ultimately dictate how the dCo source (and the resulting OMZ plumes) are affected by climate-driven changes in the size and intensity of OMZs (e.g., Scholz et al., 2011, 2014). As such, there is a significant need for future experimental and field studies that address the redox sensitivity of dCo and other metal fluxes from coastal environments.

\subsubsection{Comparing coastal sources with the OMZ cobalt plume}

Can a terrigenous cobalt source account for the observed OMZ plume? Because lithogenic sediments along the Peru margin are delivered primarily by rivers (Scheidegger and Krissek, 1982), we can estimate a dCo flux to OMZ waters as the product of the fluvial sediment delivery to the continental shelf and the difference in $\mathrm{Co} / \mathrm{Al}$ ratios between original rocks and buried shelf sediments:

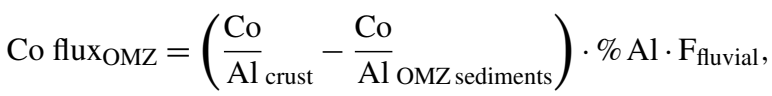

where $F_{\text {fluvial }}$ is the riverine flux of terrigenous sediments from Ecuador, Peru, and northern Chile to oxygen-depleted coastlines in the ETSP. If this supply is approximately $200 \mathrm{MT} \mathrm{yr}^{-1}$ (Lyle, 1981; Milliman and Farnsworth, 2011), the Co deficit in Peruvian sediments from Böning et al. (2004) corresponds to a $2.5-4.6 \times 10^{7} \mathrm{~mol} \mathrm{yr}^{-1}$ flux from the 
South American shelf, depending on the crustal endmember applied (upper continental crust vs. andesite, Table 2). When scaled to the size of the ETSP OMZ $\left(2.2 \times 10^{6} \mathrm{~km}^{3}\right.$ defined at $20 \mathrm{\mu M} \mathrm{O}_{2}$, Fuenzalida et al., 2009), a terrigenous cobalt supply of $11-21 \mathrm{pM} \mathrm{yr}^{-1}$ would be expected.

The extent to which the coastal flux and dCo inventory are in agreement depends on the residence time of OMZ waters. Models and CFC distributions from the World Ocean Circulation Experiment (WOCE) dataset imply an approximately decadal recirculation time in OMZ waters relative to mesopelagic gyre circulation in the ETSP (Deutsch et al., 2001, 2011). Integrating our terrigenous Co flux estimate over 10 years yields an expected concentration of 120 $230 \mathrm{pM}$ within the OMZ. This is of similar magnitude but greater than the concentrations measured in the GP16 dataset (mean of $100 \pm 30 \mathrm{pM}$ ). The difference between estimated and actual dCo inventories in the OMZ is probably due to upwelling and advection by surface currents, readily seen in the dCo section (Fig. 6), which carries the remainder to the gyre.

\subsubsection{Comparison to atmospheric deposition}

We can compare the calculated sedimentary flux to an expected flux from aerosol dust dissolution. Aeolian deposition is extremely low over the South Pacific basin (Mahowald et al., 2005), except immediately offshore of Peru, where dust from the Altiplano interacts with the prevailing northward winds (Prospero and Bonatti, 1969; Scheidegger and Krissek, 1982). Model results (Mahowald et al., 2005) suggest that deposition does not exceed $0.5 \mathrm{~g} \mathrm{~m}^{-2} \mathrm{yr}^{-1}$, except very close to the coastline. Using this estimate, crustal cobalt abundances, and the aerial extent of the $\mathrm{OMZ}$ $\left(9.8 \times 10^{6} \mathrm{~km}^{2}\right.$, Fuenzalida et al., 2009), we estimate the aerial flux of cobalt from dust to be $1.4 \times 10^{6} \mathrm{~mol} \mathrm{yr}^{-1}$. A $10 \%$ fractional solubility for cobalt (Shelley et al., 2012) in-

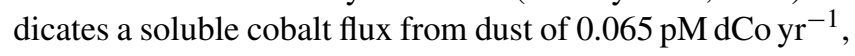
$\sim 0.5 \%$ of the expected sedimentary flux. Over a decade, dust deposition accounts for less than $1 \mathrm{pM}$ of the OMZ dCo plume. dCo profiles also lack surface maxima near shore despite corresponding features for dissolved $\mathrm{Al}$ and $\mathrm{Mn}$ at stations 1 and 5 (Fig. 10; Resing et al., 2015). Fluvial sediment delivery to the margin, therefore, is a much more plausible source for the elevated dCo in the ETSP OMZ.

\subsubsection{An inefficient cobalt source in hydrothermal vents}

Hydrothermal venting along the EPR provides a major source of $\mathrm{dFe}$ and $\mathrm{dMn}$ to the deep South Pacific (Resing et al., 2015) where nanomolar concentrations of both metals were measured between 2000 and $3000 \mathrm{~m}$ at the ridge crest and concentrations exceeded background values for several thousand kilometers westward. In contrast, dCo concentrations are only slightly elevated at the ridge crest (Station
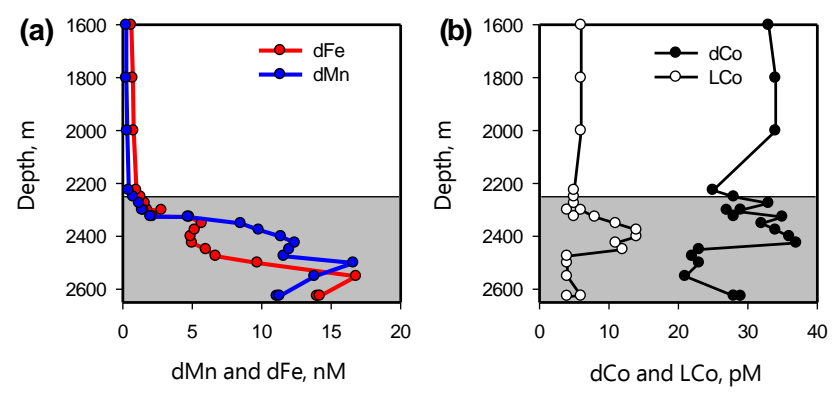

Figure 12. Profiles from Station 18 at the East Pacific Rise ridge crest at $113^{\circ} \mathrm{W}, 15^{\circ} \mathrm{S}$. (a) dMn (blue lines) and dFe profiles (red) replotted from Resing et al. (2015) clearly show hydrothermal input. Grey shading below $2250 \mathrm{~m}$ indicates area of hydrothermal influence where $\mathrm{dFe}$ and $\mathrm{dMn}$ are $>1 \mathrm{nM}$. (b) Dissolved cobalt (dCo, black circles) and labile cobalt (LCo, white) in the East Pacific Rise hydrothermal plume.

18 , Fig. 3), reaching $36 \mathrm{pM}$ at $2400 \mathrm{~m}$ (against a background of $\sim 25 \mathrm{pM}$ ); at the same station, $\mathrm{dFe}$ and $\mathrm{dMn}$ both exceeded $15 \mathrm{nM}$ (background $<1 \mathrm{nM}$, Fig. 12a). Unambiguous hydrothermal input is evident from the LCo profile, which peaks at $14 \mathrm{pM}$ at the dCo maximum (Fig. 12b), roughly consistent with a 10000 -fold dilution of high-temperature endmember sources containing $100-1000 \mathrm{nMdCo}$ (Lupton et al., 1985; Metz and Trefry, 2000).

However, both dCo and LCo maxima are offset from $\mathrm{dFe}$ and $\mathrm{dMn}$ plumes. At Station 18, dFe and dMn peak at 2500$2600 \mathrm{~m}$. At this depth, LCo is undetectable and dCo values are at - or slightly lower than - background levels (Fig. 12b), suggesting that $\mathrm{Mn}$ and/or Fe scavenging in the heart of the hydrothermal plume has removed most of the hydrothermal Co from the water column before being transported away from the ridge crest. Indeed, Co is strongly associated with Mn phases in near-axis metalliferous sediment in the EPR at $14^{\circ} \mathrm{S}$ (Dunk and Mills, 2006). The position of the LCo maximum above the $\mathrm{dMn}$ and $\mathrm{dFe}$ maxima probably reflects lower scavenging rates outside the main plume, which may spare a fraction of the hydrothermal Co source from an otherwise immediate and total removal. Even without scavenging losses, global hydrothermal Co fluxes $\left(2.2 \mathrm{Mmol} \mathrm{yr}^{-1}\right.$; Swanner et al., 2014) are 10-25 times less than our estimated source from the Peru shelf alone, highlighting the importance of upper-ocean sources in maintaining the dCo inventory.

\subsection{Cobalt scarcity in the euphotic zone}

\subsubsection{The South Pacific gyre}

The combination of eastern boundary upwelling and a continental source produces large dCo gradients across the surface of the South Pacific Ocean (Fig. 6a). Westward, decreasing surface dCo results from phytoplankton uptake and export, reflected in strong correlations with $\mathrm{PO}_{4}$, as well as mixing with low-dCo waters from the subtropical gyre. It is interest- 
ing to note that the intercept for the $\mathrm{dCo}: \mathrm{PO}_{4}$ relationship is negative $\left(-12.8 \pm 2.6 \mu \mathrm{M} \mathrm{M}^{-1}\right.$, Fig. $\left.7 \mathrm{~b}\right)$; cobalt was depleted before $\mathrm{PO}_{4}$. This is opposite to what was observed in the Sargasso Sea, where extreme $\mathrm{PO}_{4}$ scarcity results in a positive dCo: $\mathrm{PO}_{4}$ intercept (Jakuba et al., 2008). The dCo nutricline in the South Pacific gyre ( $\sim 200 \mathrm{~m}$, Fig. 6$)$ is also deeper than corresponding features in the North and South Atlantic (Noble et al., 2012; Noble and Saito, 2016). Because winter mixed layers in the tropical South Pacific generally do not exceed $100 \mathrm{~m}$ and strong haloclines separate the oxygen minimum layer from the surface (Fiedler and Talley, 2006), convective overturning does not reach the dCo nutricline at $150-250 \mathrm{~m}$. A low vertical cobalt supply makes the South Pacific gyre an interesting counterpart to the Sargasso Sea, which experiences deep winter mixing and higher dCo (1030 pM, Dulaquais et al., 2014b; Jakuba et al., 2008; Noble and Saito, 2016), and emphasizes the importance of lateral supply mechanisms, especially eastern boundary upwelling, in maintaining the surface dCo inventory of the tropical Pacific (Saito et al., 2004).

While productivity in the South Pacific is thought to be limited by scarcity of iron and nitrogen (Moore et al., 2013; Saito et al., 2014), the extremely low dCo measured here implies that it may be important as well. Because marine cyanobacteria such as Prochlorococcus and Synechococcus have an absolute Co requirement (Saito et al., 2002; Sunda and Huntsman, 1995), they are vulnerable to limitation. Indeed, a Synechococcus bloom in the Costa Rica Dome was found to be co-limited by both iron and cobalt (Saito et al., 2005). Despite dCo concentrations below $10 \mathrm{pM}$ (sometimes below the $3 \mathrm{pM}$ detection limit), the South Pacific gyre contains a significant Prochlorococcus population - evident in the high proportion of divinyl chlorophyll A to total chlorophyll (Fig. 13a). As LCo was undetectable beyond $100^{\circ} \mathrm{W}$, biological uptake must occur either by accessing strongly bound dCo or through fast recycling of LCo at very low steady-state concentrations. During GP16, particulate-Co concentrations in the upper $50 \mathrm{~m}$ were steady $(3.5 \pm 1.2 \mathrm{pM})$ and mostly reflect Co bound in biomass (Ohnemus et al., 2016), sometimes rivaling dissolved cobalt concentrations (Fig. 13b). Compared to low pCo:dCo ratios observed in the South Atlantic ( $<1: 12$, Noble et al., 2012), the high ratio in the South Pacific gyre $(\sim 1: 3$, Fig. 13b) indicates that resident Prochlorococcus are extremely well-adapted to widespread dCo scarcity and that efficient recycling of biogenic pCo may be crucial to the survival of Prochlorococcus and other cyanobacteria (e.g., Synechococcus, Ahlgren et al., 2014) in the face of widespread dCo scarcity.

\subsubsection{Depletion of labile dissolved cobalt in the Peru upwelling ecosystem}

Unlike its near uniform relationship with dCo in the underlying OMZ, LCo measured during GP16 is low relative to dCo in the surface ocean $(0-50 \mathrm{~m})$, especially along (a)

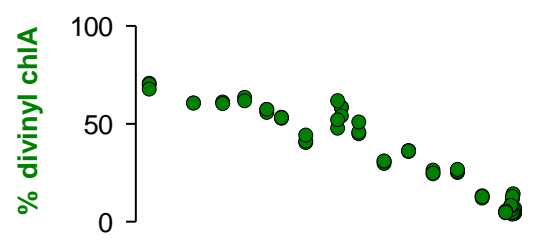

(b)

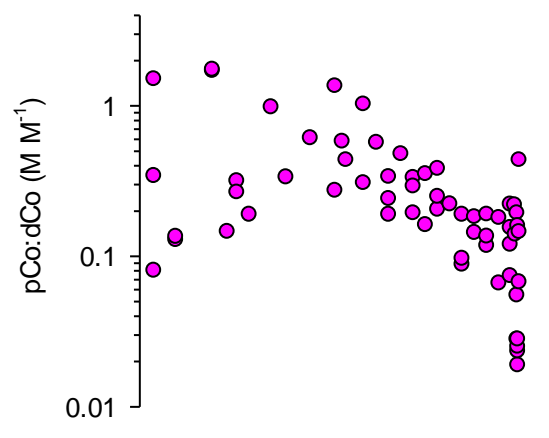

(c)

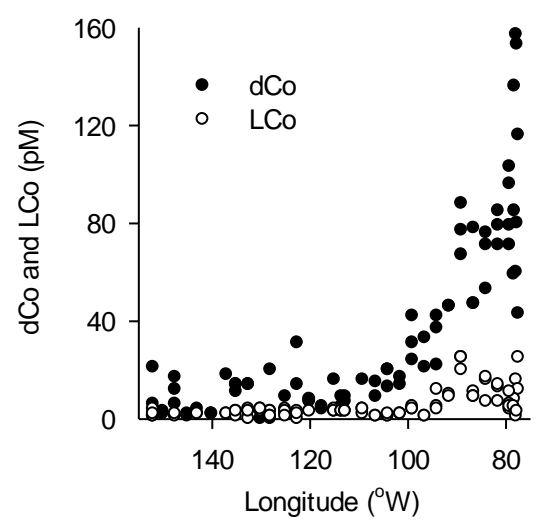

Figure 13. (a) The ratio of divinyl chlorophyll A to total chlorophyll (green circles), an indication of Prochlorococcus abundance relative to other phytoplankton. (b) The particulate-to-dissolved ratio of cobalt ( $\mathrm{pCo}: \mathrm{dCo}$, in $\mathrm{MM}^{-1}$, pink circles) in near-surface samples $(0-50 \mathrm{~m})$ measured during GP16; a value of 1 indicates equal concentrations in each phase. (c) The near-surface distribution of dissolved cobalt (dCo, black circles) and labile cobalt (LCo, white circles), showing higher concentrations near the Peru margin $\left(<80^{\circ} \mathrm{W}\right)$ and very low dCo to the west.

the Peru margin (Figs. 7a, 13c). This might result either from microbial production of cobalt ligands - as observed in a Synechococcus-dominated community in the Costa Rica Dome (Saito et al., 2005) and with cultured Prochlorococcus strains (Saito et al., 2002) - or if LCo is the preferred species for uptake. The latter has been demonstrated in culture with model eukaryotic algae (Sunda and Huntsman, 1995), where free Co ions are acquired by high-affinity $\mathrm{Zn}$-transporters. Because the Peru upwelling region is dominated by diatoms (Bruland et al., 2005), preferential uptake of free Co ions by these organisms is realistic and is corroborated by a strong correlation between LCo and dissolved silicate $(\mathrm{Si})$ in the upper $50 \mathrm{~m}$ of the section $\left(R^{2}=0.90\right.$, Fig. $\left.7 \mathrm{c}\right)$. As a result of 


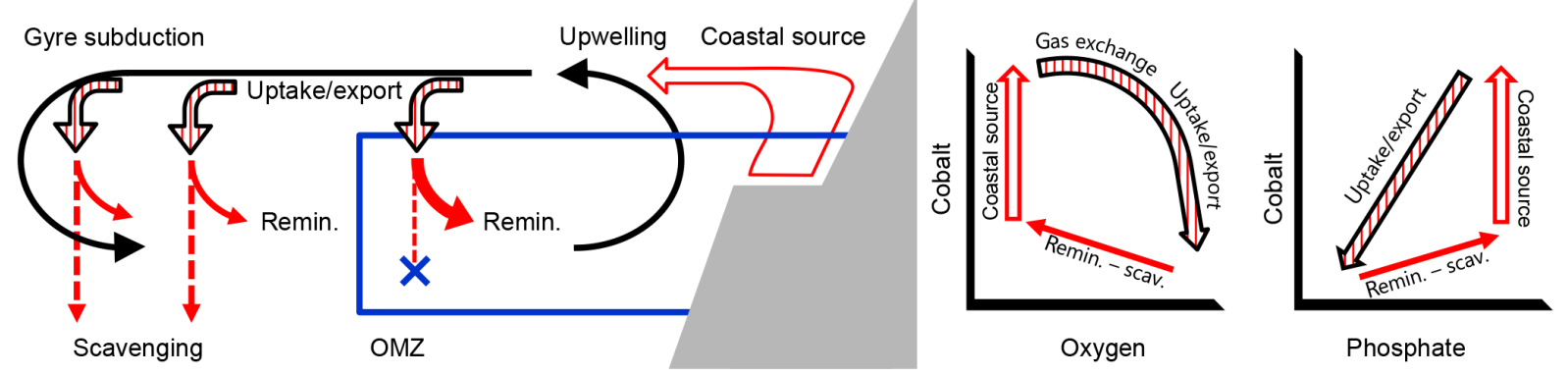

Figure 14. Schematic cross section of the cobalt cycle in the eastern tropical South Pacific. Black arrows describe idealized physical circulation, showing upwelling near the Peru margin, advection westward, and subduction in the South Pacific gyre. Biological Co export is shown in the red-striped arrows, and solid and dashed red arrows show remineralization and scavenging, respectively. The margin source is shown as a red-outlined arrow. These vectors are also plotted on idealized oxygen and phosphate axes, using the same color scheme, to show how these processes appear in $\mathrm{Co}: \mathrm{O}_{2}$ and $\mathrm{Co}: \mathrm{PO}_{4}$ space.

diatom-driven export, LCo in shelf surface waters is nearly depleted (1-12 pM) despite high concentrations of dCo (40$80 \mathrm{pM}$, Fig. 13c). Very low surface LCo at $12^{\circ} \mathrm{S}$ during GP16 contrasts with previous observations showing high concentrations of LCo in the Peru upwelling region during AugustSeptember 2000 (Saito et al., 2004). Between 5 and $10^{\circ} \mathrm{S}$, much higher surface dCo was measured in freshly upwelled waters (up to $315 \mathrm{pM}$ ) and dCo was more than $50 \%$ labile in surface transects (Saito et al., 2004). Surface dFe during August-September 2000 was also higher between 5 and $10^{\circ} \mathrm{S}$ than during GP16 at $12^{\circ} \mathrm{S}$ (Bruland et al., 2005; Resing et al., 2015). Decreasing surface $\mathrm{dFe}$ from north to south followed decreasing gradients in shelf width and fluvial sediment supply (Bruland et al., 2005; Milliman and Farnsworth, 2011), implying that the high $\mathrm{dFe}$ was due to stronger benthic sources to the north. Because coastal sources are expected to provide labile cobalt (e.g., Fig. 11), the high concentrations of LCo measured between 5 and $10^{\circ} \mathrm{S}$ during AugustSeptember 2000 indicate a similar gradient in coastal dCo input and LCo availability in surface waters.

Spatial and temporal variability of margin dCo sources may ultimately affect carbon flow through the Peru upwelling ecosystem. Considering the very low dissolved $\mathrm{Zn}$ in surface waters during GP16( $<100 \mathrm{pM}$ east of $90^{\circ} \mathrm{W}, \mathrm{S}$. John, personal communication, 2016) and that more than $95 \%$ of the $\mathrm{dZn}$ is typically complexed by organic ligands (Bruland, 1989), coastal diatoms in the Peru upwelling region may be subject to diffusion limitation when free $\mathrm{Zn}$ ions fall below a 1-10 pM threshold (Sunda and Huntsman, 1992). Because Co can replace $\mathrm{Zn}$ in carbonic anhydrase enzymes (Sunda and Huntsman, 1995; Yee and Morel, 1996), LCo supplied from the margin may maintain fast rates of carbon fixation and export in the Peru upwelling region despite low $\mathrm{dZn}$. The relatively low concentrations measured during GP16, however, imply that the LCo supply may not always be sufficient.

\section{Conclusions}

A schematic of the cobalt cycle in the eastern tropical South Pacific Ocean - and how these processes lead to covariation of dissolved cobalt with $\mathrm{O}_{2}$ and $\mathrm{PO}_{4}$ - is shown in Fig. 14. High dCo and LCo on the Peru shelf match depleted Co content reported in Peru shelf sediments and indicate a large source to the water column (Böning et al., 2004). Correlations between $\mathrm{dMn}$ and LCo in anoxic shelf waters and crustlike Co / Al ratios in oxic western boundary sediments suggest that margin cobalt sources are redox sensitive and that the sustained presence of the OMZ on the Peru margin amplifies coastal Co fluxes. The high dCo within the OMZ leads to a large flux to the surface ocean by upwelling along the Peru margin, where it is readily accessed by phytoplankton. The significance of cobalt as a micronutrient is emphasized by strong correlations with phosphate throughout the surface ocean.

The basin-scale association between high dCo and low $\mathrm{O}_{2}$ throughout the GP16 section testifies to the importance of remineralization in maintaining the $\mathrm{dCo}$ distribution in the eastern South Pacific (Fig. 14). Additionally, low oxygen suppresses particulate-Mn accumulation and Co scavenging, contributing to the OMZ cobalt plume. Scavenging in oxic mesopelagic waters limits the full return of Co to the dissolved phase during remineralization, resulting in low dissolved $\mathrm{Co}: \mathrm{P}$ ratios relative to biomass exported from the euphotic zone. Oxidative scavenging also seems to limit the flux of Co from hydrothermal venting over the East Pacific Rise, further emphasizing the Peru margin as the most important Co source to the South Pacific. Given that deep nutriclines in the South Pacific gyre limit dCo supply from vertical mixing outside of the upwelling zone, phytoplankton Co nutrition depends largely on lateral supply from the eastern margin.

Ultimately, the dCo inventory in the South Pacific - and its availability to phytoplankton - may be changing considerably as the size of the OMZ fluctuates. Recent warm- 
ing and stratification appear to have expanded the volume of low-oxygen waters in the tropics (Stramma et al., 2008, 2010). As such, dCo inventories may increase as lower $\mathrm{O}_{2}$ hinders mesopelagic Mn-oxide production and scavenging. However, decreased wind-driven upwelling and carbon export may cause anoxic waters along the shelf to contract (Deutsch et al., 2011, 2014) and decrease the efficiency of the coastal dCo source. Changes in the dCo inventory then depend on the relative redox sensitivities of margin Co sources versus offshore scavenging in the mesopelagic zone, neither of which is well understood. Considering the 100-200-year residence time of Co in the ocean (Saito and Moffett, 2002), feedbacks on the surface dCo supply may manifest more quickly than for other nutrients and may alleviate or exacerbate any existing Co limitation. Improved definition of biological Co limitation thresholds and efforts to reconstruct the Co cycle in past climates may resolve whether future changes in OMZ structure will have meaningful impacts on phytoplankton nutrition in the coming century.

\section{Data availability}

All data can be accessed on BCO-DMO (Saito, 2016; Sherrell and Twining, 2016). dCo and LCo databases can be downloaded at http://www.bco-dmo.org/dataset/642974. Particulate metal datasets can be reached at http://www. bco-dmo.org/dataset/639847.

Author contributions. N. J. Hawco, D. C. Ohnemus, and J. A. Resing participated on the EPZT cruise. N. J. Hawco measured dCo and LCo. J. A. Resing measured dMn; D. C. Ohnemus and B. S. Twining measured particulate Co, Mn, and P. N. J. Hawco and M. A. Saito prepared the manuscript with contributions from all authors.

Acknowledgements. We thank the captain and crew of the RV Thomas G. Thompson and the entirety of the science party aboard the GP16 cruise, especially chief scientists Jim Moffett and Chris German. We also thank Claire Parker and Cheryl Zurbrick for enormous efforts in sample collection, Greg Cutter and Geo Smith for operating the trace metal rosette and towfish, respectively, and Sara Rauschenberg and Rob Sherrell for particle sampling. The Oceanographic Data Facility (ODF) provided nutrient, oxygen, and salinity data, and the Bidigare Lab (UH) provided HPLC-pigment analyses. The technical and logistical expertise of Dawn Moran and Matt McIlvin is unparalleled. We appreciate the efforts of the GEOTRACES office in coordinating the GP16 expedition and thank Luca Pini and Mike Kubicsko of Metrohm Autolab for assistance with voltammetry. This is PMEL publication no. 4475 and JISAO publication 2648. This work was funded by NSF awards OCE-1233733 to MAS, OCE-1232814 to BST, and OCE-1237011 to JAR.

Edited by: C. P. Slomp

Reviewed by: two anonymous referees

\section{References}

Ahlgren, N. A., Noble, A. E., Patton, A. P., Roache-Johnson, K., Jackson, L., Robinson, D., McKay, C., Moore, L. R., Saito, M. A., and Rocap, G.: The unique trace metal and mixed layer conditions of the Costa Rica upwelling dome support a distinct and dense community of Synechococcus, Limnol. Oceanogr., 59, 2166-2184, doi:10.4319/lo.2014.59.6.2166, 2014.

Alongi, D. M., Boyle, S. G., Tirendi, F., and Payn, C.: Composition and Behaviour of Trace Metals in Post-oxic Sediments of the Gulf of Papua, Papua New Guinea, Estuar. Coast. Shelf S., 42, 197-211, doi:10.1006/ecss.1996.0015, 1996.

Baars, O. and Croot, P. L.: Dissolved cobalt speciation and reactivity in the eastern tropical North Atlantic, Mar. Chem., doi:10.1016/j.marchem.2014.10.006, 2015.

Baxter, L. A., Bobrowski, A., Bond, A. M., Heath, G. A, Paul, R. L., Mrzljak, R., and Zarebski, J.: Electrochemical and spectroscopic investigation of the reduction of dimethylglyoxime at mercury electrodes in the presence of cobalt and nickel, Anal. Chem., 70, 1312-1323, doi:10.1021/ac9703616, 1998.

Biller, D. V. and Bruland, K. W.: Sources and distributions of $\mathrm{Mn}, \mathrm{Fe}, \mathrm{Co}, \mathrm{Ni}, \mathrm{Cu}, \mathrm{Zn}$, and $\mathrm{Cd}$ relative to macronutrients along the central California coast during the spring and summer upwelling season, Mar. Chem., 155, 50-70, doi:10.1016/j.marchem.2013.06.003, 2013.

Böning, P., Brumsack, H. J., Böttcher, M. E., Schnetger, B., Kriete, C., Kallmeyer, J., and Borchers, S. L.: Geochemistry of Peruvian near-surface sediments, Geochim. Cosmochim. Ac., 68, 44294451, doi:10.1016/j.gca.2004.04.027, 2004.

Böning, P., Brumsack, H. J., Schnetger, B., and Grunwald, M.: Trace element signatures of Chilean upwelling sediments at $\sim 36^{\circ} \mathrm{S}$, Mar. Geol., 259, 112-121, doi:10.1016/j.margeo.2009.01.004, 2009.

Borchers, S. L., Schnetger, B., Böning, P., and Brumsack, H.-J.: Geochemical signatures of the Namibian diatom belt: Perennial upwelling and intermittent anoxia, Geochem., Geophys. Geosyst., 6, Q06006, doi:10.1029/2004GC000886, 2005.

Bown, J., Boye, M., Baker, A., Duvieilbourg, E., Lacan, F., Le Moigne, F., Planchon, F., Speich, S., and Nelson, D. M.: The biogeochemical cycle of dissolved cobalt in the Atlantic and the Southern Ocean south off the coast of South Africa, Mar. Chem., 126, 193-206, doi:10.1016/j.marchem.2011.03.008, 2011.

Bown, J., Boye, M., and Nelson, D. M.: New insights on the role of organic speciation in the biogeochemical cycle of dissolved cobalt in the southeastern Atlantic and the Southern Ocean, Biogeosciences, 9, 2719-2736, doi:10.5194/bg-9-2719-2012, 2012.

Bremner, J. M. and Willis, J. P.: Mineralogy and geochemistry of the clay fraction of sediments from the Namibian continental margin and the adjacent hinterland, Mar. Geol., 115, 85-116, doi:10.1016/0025-3227(93)90076-8, 1993.

Bruland, K. W.: Complexation of zinc by natural organic ligands in the central North Pacific, Limnol. Oceanogr., 34, 269-285, doi:10.4319/lo.1989.34.2.0269, 1989.

Bruland, K. W. and Lohan, M. C.: Controls of Trace Metals in Seawater, Treatise Geochemistry Second Ed., 6, 23-47, doi:10.1016/B978-0-08-095975-7.00602-1, 2003.

Bruland, K. W., Rue, E. L., Smith, G. J., and DiTullio, G. R.: Iron, macronutrients and diatom blooms in the Peru upwelling regime: brown and blue waters of Peru, Mar. Chem., 93, 81-103, doi:10.1016/j.marchem.2004.06.011, 2005. 
Brumsack, H. J.: Geochemistry of recent TOC-rich sediments from the Gulf of California and the Black Sea, Geol. Rundsch., 78, 851-882, doi:10.1007/BF01829327, 1989.

Brumsack, H. J.: The trace metal content of recent organic carbon-rich sediments: Implications for Cretaceous black shale formation, Palaeogeogr. Palaeoecl., 232, 344-361, doi:10.1016/j.palaeo.2005.05.011, 2006.

Chang, B. X., Devol, A. H., and Emerson, S. R.: Denitrification and the nitrogen gas excess in the eastern tropical South Pacific oxygen deficient zone, Deep-Sea Res. Pt. I, 57, 1092-1101, doi:10.1016/j.dsr.2010.05.009, 2010.

Cowen, J. P. and Bruland, K. W.: Metal deposits associated with bacteria: implications for Fe and Mn marine biogeochemistry, Deep-Sea Res., 32, 253-272, doi:10.1016/0198-0149(85)900780,1985 .

Cutter, G. A. and Bruland, K. W.: Rapid and noncontaminating sampling system for trace elements in global ocean surveys, Limnol. Oceanogr.-Meth., 10, 425-436, doi:10.4319/lom.2012.10.425, 2012.

Deutsch, C., Gruber, N., Key, R. M., Sarmiento, J. L., and Ganachaud, A.: Denitrification and $\mathrm{N}_{2}$ fixation in the Pacific Ocean, Global Biogeochem. Cy., 15, 483-506, doi:10.1029/2000GB001291, 2001.

Deutsch, C., Brix, H., Ito, T., and Thompson, L.: Climateforced variability of ocean hypoxia, Science, 333, 336-339, doi:10.1126/science.1202422, 2011.

Deutsch, C., Berelson, W., Thunell, R., Weber, T., Tems, C., McManus, J., Crusius, J., Ito, T., Baumgartner, T., Ferreira, V., Mey, J., and van Geen, A.: Centennial changes in North Pacific anoxia linked to tropical trade winds, Science, 345, 665-668, doi:10.1126/science.1252332, 2014

DeVries, T. and Deutsch, C.: Large-scale variations in the stoichiometry of marine organic matter respiration, Nat. Geosci., 7, 1-5, doi:10.1038/ngeo2300, 2014.

DeVries, T., Deutsch, C., Primeau, F., Chang, B., and Devol, A.: Global rates of water-column denitrification derived from nitrogen gas measurements, Nat. Geosci., 5, 547-550, doi:10.1038/ngeo1515, 2012

Dulaquais, G., Boye, M., Middag, R., Owens, S., Puigcorbe, V., Buesseler, K., Masqué, P., de Baar, H. J. W., and Carton, X.: Contrasting biogeochemical cycles of cobalt in the surface western Atlantic Ocean, Global Biogeochem. Cy., 28, 1387-1412, doi:10.1002/2014GB004903, 2014a.

Dulaquais, G., Boye, M., Rijkenberg, M. J. A., and Carton, X.: Physical and remineralization processes govern the cobalt distribution in the deep western Atlantic Ocean, Biogeosciences, 11, 1561-1580, doi:10.5194/bg-11-1561-2014, 2014b.

Dunk, R. M. and Mills, R. A.: The impact of oxic alteration on plume-derived transition metals in ridge flank sediments from the East Pacific Rise, Mar. Geol., 229, 133-157, doi:10.1016/j.margeo.2006.03.007, 2006.

Dunlea, A. G., Murray, R. W., and Harris, R. N.: Cobaltbased age models of pelagic clay in the South Pacific Gyre, Geochem., Geophys. Geosyst., 16, 2964-2710, doi:10.1029/2004GC000886, 2015.

Ellwood, M. J. and van den Berg, C. M.: Determination of organic complexation of cobalt in seawater by cathodic stripping voltammetry, Mar. Chem., 75, 33-47, doi:10.1016/S03044203(01)00024-X, 2001.
Fiedler, P. C. and Talley, L. D.: Hydrography of the eastern tropical Pacific: A review, Prog. Oceanogr., 69, 143-180, doi:10.1016/j.pocean.2006.03.008, 2006.

Fuenzalida, R., Schneider, W., Garcés-Vargas, J., Bravo, L., and Lange, C.: Vertical and horizontal extension of the oxygen minimum zone in the eastern South Pacific Ocean, Deep-Sea Res. Pt. II, 56, 992-1003, doi:10.1016/j.dsr2.2008.11.001, 2009.

Gaillardet, J., Viers, J., and Dupré, B.: Trace Elements in River Waters, in: Treatise on Geochemistry, 5, 225-272, Pergamon Press, Oxford, UK, 2003.

Goldberg, E. D. and Arrhenius, G. O. S.: Chemistry of Pacific pelagic sediments, Geochim. Cosmochim. Ac., 13, 153-212, doi:10.1016/0016-7037(58)90046-2, 1958.

Heggie, D. and Lewis, T.: Cobalt in pore waters of marine sediments, Nature, 311, 453-455, doi:10.1038/311453a0, 1984.

Hu, D., Böning, P., Köhler, C. M., Hillier, S., Pressling, N., Wan, S., Brumsack, H. J., and Clift, P. D.: Deep sea records of the continental weathering and erosion response to East Asian monsoon intensification since $14 \mathrm{ka}$ in the South China Sea, Chem. Geol., 326-327, 1-18, doi:10.1016/j.chemgeo.2012.07.024, 2012.

Hu, D., Clift, P. D., Boning, P., Hannigan, R., Hillier, S., Blusztajn, J., Wan, S., and Fuller, D. Q.: Holocene evolution in weathering and erosion patterns in the Pearl River delta, Geochem., Geophys. Geosyst., 14, 2349-2368, doi:10.1002/ggge.20166, 2013.

Jakuba, R. W., Moffett, J. W., and Dyhrman, S. T.: Evidence for the linked biogeochemical cycling of zinc, cobalt, and phosphorus in the western North Atlantic Ocean, Global Biogeochem. Cy., 22, 1-13, doi:10.1029/2007GB003119, 2008.

Johnson, K. S., Stout, P. M., Berelson, W. M., and SakamotoArnold, C. M.: Cobalt and copper distributions in the waters of Santa Monica Basin, California, Nature, 332, 527-530, doi:10.1038/332527a0, 1988.

Johnson, K. S., Coale, K. H., Berelson, W. M., and Michael Gordon, R.: On the formation of the manganese maximum in the oxygen minimum, Geochim. Cosmochim. Ac., 60, 1291-1299, doi:10.1016/0016-7037(96)00005-1, 1996.

Karstensen, J., Stramma, L., and Visbeck, M.: Oxygen minimum zones in the eastern tropical Atlantic and Pacific oceans, Prog. Oceanogr., 77, 331-350, doi:10.1016/j.pocean.2007.05.009, 2008.

Knauer, G. A., Martin, J. H., and Gordon, R. M.: Cobalt in northeast Pacific waters, Nature, 297, 49-51, doi:10.1038/297049a0, 1982.

Lupton, J. E., Delaney, J. R., Johnson, H. P., and Tivey, M. K.: Entrainment and vertical transport of deep-ocean water by buoyant hydrothermal plumes, Nature, 316, 621-623, doi:10.1038/316621a0, 1985.

Lyle, M.: Formation and growth of ferromanganese oxides on the Nazca plate, Geol. Soc. Am. Mem., 154, 269-295, doi:10.1130/MEM154-p269, 1981.

Mahowald, N. M., Baker, A. R., Bergametti, G., Brooks, N., Duce, R. A., Jickells, T. D., Kubilay, N., Prospero, J. M., and Tegen, I.: Atmospheric global dust cycle and iron inputs to the ocean, Global Biogeochem. Cy., 19, GB4025, doi:10.1029/2004GB002402, 2005.

McLennan, S. M.: Relationships between the trace element composition of sedimentary rocks and upper continental crust, Geochem., Geophys. Geosyst., 2, 1021, doi:10.1029/2000GC000109, 2001. 
Metz, S. and Trefry, J. H.: Chemical and mineralogical influences on concentrations of trace metals in hydrothermal fluids, Geochim. Cosmochim. Ac., 64, 2267-2279, doi:10.1016/S00167037(00)00354-9, 2000.

Milliman, J. D. and Farnsworth, K. L.: River Discharge to the Coastal Ocean, Cambridge University Press, Cambridge, UK, 2011.

Moffett, J. W.: A radiotracer study of cerium and manganese uptake onto suspended particles in Chesapeake Bay, Geochim. Cosmochim. Ac., 58, 695-703, doi:10.1016/0016-7037(94)90499-5, 1994.

Moffett, J. W. and Ho, J.: Oxidation of cobalt and manganese in seawater via a common microbially catalyzed pathway, Geochim. Cosmochim. Ac., 60, 3415-3424, doi:10.1016/00167037(96)00176-7, 1996.

Moore, C. M., Mills, M. M., Arrigo, K. R., Berman-Frank, I., Bopp, L., Boyd, P. W., Galbraith, E. D., Geider, R. J., Guieu, C., Jaccard, S. L., Jickells, T. D., La Roche, J., Lenton, T. M., Mahowald, N. M., Marañón, E., Marinov, I., Moore, J. K., Nakatsuka, T., Oschlies, A., Saito, M. A, Thingstad, T. F., Tsuda, A., and Ulloa, O.: Processes and patterns of oceanic nutrient limitation, Nat. Geosci., 6, 701-710, doi:10.1038/ngeo1765, 2013.

Morse, J. W. and Luther, G. W.: Chemical influence on trace metalsulfide interactions in anoxic sediments, Geochim. Cosmochim. Ac., 63, 3373-3378, 1999.

Noble, A. E. and Saito, M. A.: Total Dissolved Cobalt and Cobalt Speciation from the US North Atlantic GEOTRACES Zonal Transect, in prep, 2016.

Noble, A. E., Saito, M. A., Maiti, K., and Benitez-Nelson, C. R.: Cobalt, manganese, and iron near the Hawaiian Islands: A potential concentrating mechanism for cobalt within a cyclonic eddy and implications for the hybrid-type trace metals, Deep-Sea Res. Pt. II, 55, 1473-1490, doi:10.1016/j.dsr2.2008.02.010, 2008.

Noble, A. E., Lamborg, C. H., Ohnemus, D. C., Lam, P. J., Goepfert, T. J., Measures, C. I., Frame, C. H., Casciotti, K. L., DiTullio, G. R., Jennings, J., and Saito, M. A.: Basin-scale inputs of cobalt, iron, and manganese from the Benguela-Angola front to the South Atlantic Ocean, Limnol. Oceanogr., 57, 989-1010, doi:10.4319/lo.2012.57.4.0989, 2012.

Ohnemus, D., Rauschenberg, S., Cutter, G. A., and Twining, B. S.: Elevated trace metal content of prokaryotic plankton communities associated with anoxic marine zones, Limnol. Oceanogr., doi:10.1002/lno.10363, in press, 2016.

Price, N. M., Harrison, G. I., Hering, J. G., Hudson, R. J., Nirel, P. M. V., Palenik, B., and Morel, F. M. M.: Preparation and Chemistry of the Artificial Algal Culture Medium Aquil, Biol. Oceanogr., 6, 443-461, doi:10.1080/01965581.1988.10749544, 1989.

Prospero, J. M. and Bonatti, E.: Continental dust in the atmosphere of the Eastern Equatorial Pacific, J. Geophys. Res., 74, 33623371, doi:10.1029/JC074i013p03362, 1969.

Resing, J. A., Sedwick, P. N., German, C. R., Jenkins, W. J., Moffett, J. W., Sohst, B. M., and Tagliabue, A.: Basin-scale transport of hydrothermal dissolved metals across the South Pacific Ocean, Nature, 523, 200-203, doi:10.1038/nature14577, 2015.

Saito, M. A.: Dataset: Cobalt Total and Labile Dissolved, Biological and Chemical Oceanography Data Management Office (BCODMO), Dataset version: 1 July 2016, available at: http://www. bco-dmo.org/dataset/642974, last access: 12 October 2016.
Saito, M. A. and Moffett, J. W.: Complexation of cobalt by natural organic ligands in the Sargasso Sea as determined by a new highsensitivity electrochemical cobalt speciation method suitable for open ocean work, Mar. Chem., 75, 49-68, doi:10.1016/S03044203(01)00025-1, 2001.

Saito, M. A. and Moffett, J. W.: Temporal and spatial variability of cobalt in the Atlantic Ocean, Geochim. Cosmochim. Ac., 66, 1943-1953, doi:10.1016/S0016-7037(02)00829-3, 2002.

Saito, M. A., Moffett, J. W., Chisholm, S. W., and Waterbury, J. B.: Cobalt limitation and uptake in Prochlorococcus, Limnol. Oceanogr., 47, 1629-1636, doi:10.4319/lo.2002.47.6.1629, 2002.

Saito, M. A., Moffett, J. W., and DiTullio, G. R.: Cobalt and nickel in the Peru upwelling region: A major flux of labile cobalt utilized as a micronutrient, Global Biogeochem. Cy., 18, GB4030, doi:10.1029/2003GB002216, 2004.

Saito, M. A., Rocap, G., and Moffett, J. W.: Production of cobalt binding ligands in a Synechococcus feature at the Costa Rica upwelling dome, Limnol. Oceanogr., 50, 279-290, doi:10.4319/lo.2005.50.1.0279, 2005.

Saito, M. A., Goepfert, T. J., Noble, A. E., Bertrand, E. M., Sedwick, P. N., and DiTullio, G. R.: A seasonal study of dissolved cobalt in the Ross Sea, Antarctica: micronutrient behavior, absence of scavenging, and relationships with $\mathrm{Zn}, \mathrm{Cd}$, and P, Biogeosciences, 7, 4059-4082, doi:10.5194/bg-7-4059-2010, 2010.

Saito, M. A., McIlvin, M. R., Moran, D. M., Goepfert, T. J., DiTullio, G. R., Post, A. F., and Lamborg, C. H.: Multiple nutrient stresses at intersecting Pacific Ocean biomes detected by protein biomarkers, Science, 345, 1173-1177, doi:10.1126/science.1256450, 2014.

Sarmiento, J. L., Gruber, N., Brzezinski, M. A., and Dunne, J. P.: High-latitude controls of thermocline nutrients and low latitude biological productivity, Nature, 479, 556-556, doi:10.1038/nature10605, 2011.

Scheidegger, K. F. and Krissek, L. A.: Dispersal and deposition of eolian and fluvial sediments off Peru and northern Chile, Geol. Soc. Am. Bull., 93, 150-162, doi:10.1130/00167606(1982)93<150:DADOEA>2.0.CO;2, 1982.

Scholz, F., Hensen, C., Noffke, A., Rohde, A., Liebetrau, V., and Wallmann, K.: Early diagenesis of redox-sensitive trace metals in the Peru upwelling area - response to ENSO-related oxygen fluctuations in the water column, Geochim. Cosmochim. Ac., 75, 7257-7276, doi:10.1016/j.gca.2011.08.007, 2011.

Scholz, F., McManus, J., Mix, A. C., Hensen, C., and Schneider, R. R.: The impact of ocean deoxygenation on iron release from continental margin sediments, Nat. Geosci., 7, 433-437, doi:10.1038/ngeo2162, 2014.

Shaked, Y., Xu, Y., Leblanc, K., and Morel, F. M. M.: Zinc availability and alkaline phosphatase activity in Emiliania huxleyi: Implications for $\mathrm{Zn}-\mathrm{P}$ co-limitation in the ocean, Limnol. Oceanogr., 51, 299-309, doi:10.4319/lo.2006.51.1.0299, 2006.

Shelley, R. U., Sedwick, P. N., Bibby, T. S., Cabedo-Sanz, P., Church, T. M., Johnson, R. J., Macey, A. I., Marsay, C. M., Sholkovitz, E. R., Ussher, S. J., Worsfold, P. J., and Lohan, M. C.: Controls on dissolved cobalt in surface waters of the Sargasso Sea: Comparisons with iron and aluminum, Global Biogeochem. Cy., 26, GB2020, doi:10.1029/2011GB004155, 2012.

Sherrell, R. M. and Twining B. S.: Dataset: Particulate Elements Go-Flo Bottle, Biological and Chemical Oceanography Data 
Management Office (BCO-DMO), Dataset version: 17 May 2016, available at: http://www.bco-dmo.org/dataset/639847, last access: 12 October 2016.

Sholkovitz, E. R. and Copland, D.: The coagulation, solubility and adsorption properties of $\mathrm{Fe}, \mathrm{Mn}, \mathrm{Cu}, \mathrm{Ni}, \mathrm{Cd}, \mathrm{Co}$ and humic acids in a river water, Geochim. Cosmochim. Ac., 45, 181-189, doi:10.1016/0016-7037(81)90161-7, 1981.

Slemons, L. O., Murray, J. W., Resing, J., Paul, B., and Dutrieux, P.: Western Pacific coastal sources of iron, manganese, and aluminum to the Equatorial Undercurrent, Global Biogeochem. Cy., 24, GB3024, doi:10.1029/2009GB003693, 2010.

Stramma, L., Johnson, G. C., Sprintall, J., and Mohrholz, V.: Expanding Oxygen-Minimum Zones in the Tropical Oceans, Science, 320, 655-658, doi:10.1126/science.1153847, 2008.

Stramma, L., Johnson, G. C., Firing, E., and Schmidtko, S.: Eastern Pacific oxygen minimum zones: Supply paths and multidecadal changes, J. Geophys. Res., 115, C09011, doi:10.1029/2009JC005976, 2010.

Sunda, W. G. and Huntsman, S. A.: Microbial oxidation of manganese in a North Carolina estuary, Limnol. Oceanogr., 32, 552564, doi:10.4319/lo.1987.32.3.0552, 1987.

Sunda, W. G. and Huntsman, S. A.: Diel cycles in microbial manganese oxidation and manganese redox speciation in coastal waters of the Bahama Islands, Limnol. Oceanogr., 35, 325-338, doi:10.4319/lo.1990.35.2.0325, 1990.

Sunda, W. G. and Huntsman, S. A.: Feedback interactions between zinc and phytoplankton in seawater, Limnol. Oceanogr., 37, 2540, doi:10.4319/lo.1992.37.1.0025, 1992

Sunda, W. G. and Huntsman, S. A.: Cobalt and zinc interreplacement in marine phytoplankton: biological and geochemical implications, Limnol. Oceanogr., 40, 1404-1417, doi:10.4319/lo.1995.40.8.1404, 1995.

Sundby, B., Anderson, L. G., Hall, P. O. J., Iverfeldt, Å., van der Loeff, M. M. R., and Westerlund, S. F. G.: The effect of oxygen on release and uptake of cobalt, manganese, iron and phosphate at the sediment-water interface, Geochim. Cosmochim. Ac., 50, 1281-1288, doi:10.1016/0016-7037(86)90411-4, 1986.
Swanner, E. D., Planavsky, N. J., Lalonde, S. V., Robbins, L. J., Bekker, A., Rouxel, O. J., Saito, M. A., Kappler, A., Mojzsis, S. J., and Konhauser, K. O.: Cobalt and marine redox evolution, Earth Planet. Sci. Lett., 390, 253-263, doi:10.1016/j.epsl.2014.01.001, 2014.

Taylor, S. R. and McLennan, S. M.: The geochemical evolution of the continental crust, Rev. Geophys., 33, 241-265, doi:10.1029/95RG00262, 1995.

Toggweiler, J. R., Dixon, K., and Broecker, W. S.: The Peru upwelling and the ventilation of the South Pacific thermocline, J. Geophys. Res., 96, 20467, doi:10.1029/91JC02063, 1991.

Tovar-Sánchez, A., Sañudo-Wilhelmy, S. A., and Flegal, A. R.: Temporal and spatial variations in the biogeochemical cycling of cobalt in two urban estuaries: Hudson River Estuary and San Francisco Bay, Estuar. Coast. Shelf S., 60, 717-728, doi:10.1016/j.ecss.2004.03.010, 2004.

Twining, B. S. and Baines, S. B.: The Trace Metal Composition of Marine Phytoplankton, Ann. Rev. Mar. Sci., 5, 191-215, doi:10.1146/annurev-marine-121211-172322, 2013.

Ulloa, O., Canfield, D. E., DeLong, E. F., Letelier, R. M., and Stewart, F. J.: Microbial oceanography of anoxic oxygen minimum zones., P. Natl. Acad. Sci. USA, 109, 15996-6003, doi:10.1073/pnas.1205009109, 2012.

von Langen, P. J., Johnson, K. S., Coale, K. H., and Elrod, V. A.: Oxidation kinetics of manganese (II) in seawater at nanomolar concentrations, Geochim. Cosmochim. Ac., 61, 4945-4954, doi:10.1016/S0016-7037(97)00355-4, 1997.

Yee, D. and Morel, F. M. M.: In vivo substitution of zinc by cobalt in carbonic anhydrase of a marine diatom, Limnol. Oceanogr., 41, 573-577, doi:10.4319/lo.1996.41.3.0573, 1996. 